Article

\title{
Cajamarca: Mapping (Post)Mining Palimpsests of the Peruvian Andes
}

\author{
Margarita Macera *, Bruno De Meulder and Kelly Shannon \\ Department of Architecture, KU Leuven, 3001 Leuven, Belgium; \\ E-Mails: margaritaasuncion.maceracarnero@student.kuleuven.be (M.M.), bruno.demeulder@kuleuven.be (B.D.M.), \\ kelly.shannon@kuleuven.be (K.S.) \\ * Corresponding author
}

Submitted: 16 January 2020 | Accepted: 27 April 2020 | Published: 30 June 2020

\begin{abstract}
Mining, in addition to other human activities and natural phenomena, has repeatedly reshaped the landscapes of the Peruvian Andes. Long-standing, significantly modified and new Andean landscapes have resulted in a complex reading of the 'land as palimpsest' (Corboz, 1983). In recent decades, large-scale modern mining has disturbed headwater landscapes and broader Andean ecologies, as exemplified in Cajamarca's gold mines. This article critically reads past and present spatial transformations induced by gold mining in the headwaters of the Cajamarca Basin. Through archival documentation, fieldwork and interpretative cartography, it analyses the large-scale surface mining operations in Cajamarca from 1993 to 2020 , as well as their impact on downstream rural and urban ecologies. A cross-scalar mapping investigation discloses the spatial-ecological outcomes of twenty-seven years of mining (and closure) operational procedures. As a conclusion of the palimpsest reading, a design-research question is posed as to how Cajamarca's post-mining landscapes can be opportunely premeditated. It hypothesizes that, already during exploitation, the post-mining landscapes can be consciously constructed by an intelligent manipulation of mining procedures and create a layer of the territory that is more robust. Environmental reconstruction after mining closure recreates a pseudo-natural environment that supposedly erases the traces of mining and restores natural condition-literally back to nature, with no cultural trace. In this regard, reconstruction is merely theoretical since the repairing to a natural state would mean no palimpsests. However, despite the most imaginative and ecological repair, the territory remains a mega palimpsest, cruelly violated and disrupted. Therefore, at best, the proposition can be to build a cultural, consciously conceived and tailored post-mining landscape, merging mining and post-mining landscape construction into one movement, where the remaining (palimpsest) is part-and-parcel of the newly constructed.
\end{abstract}

\section{Keywords}

Andes; Cajamarca; palimpsest; (post)mining landscapes; reconstruction

Issue

This article is part of the issue "Territories in Time: Mapping Palimpsest Horizons" edited by Chiara Cavalieri (UCLouvain, Belgium) and Elena Cogato (EPFL, Switzerland).

(C) 2020 by the authors; licensee Cogitatio (Lisbon, Portugal). This article is licensed under a Creative Commons Attribution 4.0 International License (CC BY).

\section{Introduction}

In addition to other human activities and natural phenomenon, resource extraction has repeatedly reshaped the Peruvian Andes landscapes. Since early human occupation $(20,000 \mathrm{BC})$, a steady process of landscape domestication and colonization has challenged the territory's inhospitable environmental conditions. Since the $16^{\text {th }}$ century, processes of colonial resettlement and intensive re- source extraction introduced new landscape configurations while ancient ones receded. Long-standing, significantly modified or abandoned and new Andean landscapes have resulted in a complex condition of the 'land as palimpsest' (Corboz, 1983). In recent decades, largescale modern mining has continuously reshaped headwater landscapes and broader Andean ecologies, as exemplified in Cajamarca. In parallel to relentless surface gold extraction are ecological restoration activities. Although 
they comply with international standards of post-mining rehabilitation, Cajamarca's mining closure procedures remain detached from its historical development. Indeed, it could be argued that generic reconstruction of landscapes and ecologies in the North Andean headwaters are yet another brutal landscape disturbance.

Sustainable post-mining development in Cajamarca - as in other Andean regions-requires a critical reading of its long-term history in order to inform the design of resilient landscapes and ecologies. A post-mining design project in Cajamarca necessitates looking beyond the timeframe and physical boundaries of mining activities. It entails the identification of resilient Andean ecologies.

\section{Methods and Objectives}

This article critically reads past and present spatial transformations induced by human activities and mining (and closure) in the Peruvian Andes (from $4^{\circ} \mathrm{S}$ to $18^{\circ} \mathrm{S}$ latitudes) and the headwaters of the Cajamarca Basin ( $7^{\circ} \mathrm{S}$ latitude). It is based on a literature review and interpretative cartography. The work is premised on fieldwork trips in 2015, 2017 and 2018, which included visits to the mining sites and the larger territory as well as informal interviews with key stakeholders. The research seeks to contextualize Cajamarca's landscape evolution within the broader history of the Andes. The Cajamarca Basin has been occupied by mining operations since 1993. The analysis focuses on the manipulation of topography and water as disturbance ecologies.

In order to address dynamics at different altitudes, parallel sections across scales were systematically overlaid. The mapping methods relate to those of Alexander von Humboldt (1805) and Paz Soldán (1865a), which incorporate empirical and interpretative components of the Andean environment. The interpretative mapping developed for Cajamarca's (post)mining landscapes allows for their problematization and discloses future potentials.

The first section of this article sheds light on the dynamic configuration of the Andean environment and the resilient ecologies of the Andes and Cajamarca until Spanish colonization (16th century). The next section illustrates successive waves of ecological disturbance and landscape transformation until the establishment of modern mining in Cajamarca and the Andean region (20th century). In the third section, there is a critical review of the mining (and mining closure) operations in Cajamarca's headwaters from 1993 to 2020, as well as their impact in the basin's downstream rural and urban ecologies. The cross-scalar mapping investigation discloses and contextualizes the spatial-ecological outcomes of twenty-seven years of mining (and closure) operational procedures.

The reading of the territory as a palimpsest led to a design-research question: How can Cajamarca's post-mining landscapes be premeditated and recontextualized within the landscape's longue-durée?
There is the hypothesis that, during exploitation, postmining landscapes can be consciously constructed by an intelligent manipulation of mining operation procedures and create more robust territory. Despite the most imaginative processes of ecological repair, Cajamarca's cruelly manipulated territory remains disturbed. The proposition is to build a cultural, consciously conceived and tailored postmining landscape, which merges mining and postmining landscapes where the remaining (palimpsest) is part-and-parcel of a new constructed environment.

\section{Andean and Cajamarca's Palimpsests}

The Andes have their origins in the accelerated convergence and subduction of the Nazca Ocean Plate below the Continental Plate of South America, which occurred twenty-five million years ago (Montgomery, Balco, \& Willett, 2017). From $5^{\circ} \mathrm{N}$ to $45^{\circ} \mathrm{S}$ latitudes, seven thousand kilometres of uplifted ocean sediments and 'trapped' mineralized areas were the result of its orogenesis. Multi-metallic deposits are disseminated across the Andes (Purser \& Purser, 1971). Problematically, they are mostly concentrated in headwater areas, which are vital to the hydric balance of local, regional and continental ecologies. The Andean geography comprises an array of hypsometric conditions. Its abrupt altitudinal variations generate a direct proportional variation in microclimates and life zones (Tosi, 1960).

Indigenous populations of the Peruvian Andes $\left(4^{\circ} \mathrm{S}\right.$ to $18^{\circ} \mathrm{S}$ latitudes) identify eight 'ecological floors,' each which is comprised of specific climatic conditions in correspondence to variations in altitude (Pulgar Vidal, 1946, 1996; Troll, 1962). Each 'floor' contains specific climatic conditions, relief, (sub)soil, hydrology, flora and fauna (Pulgar Vidal, 1946). Of particular ecological importance are the higher ecological floors: suni (from $7^{\circ} \mathrm{S}$ to $18^{\circ} \mathrm{S}$ latitudes) or jalca (from $4^{\circ} \mathrm{S}$ to $7^{\circ} \mathrm{S}$ latitudes)-also denominated páramo above the $4^{\circ} \mathrm{S}$ latitude-which are positioned above 3,500 meters altitude and below the limits of permanent snow. Tropical, semi-tropical and semiarid climates respectively differentiate the paramo, jalca and suni. In the jalca, seasonal rains allow for the growth of natural pastures across plains and hummocks. Within each 'floor' there are additional micro-climates which are determined by sun exposure, shadows and winds.

Cajamarca ( $7^{\circ} \mathrm{S}$ latitude) is semi-tropical, located in the area between the northern tropical and the southern semi-arid Andes. Its particular geography, with proximity to the warm Pacific equatorial current in the west, and the Amazonian Forest to the east, creates the necessary moistness for the existence of unique jalca ecosystems in the basin's headwater (Galán de Mera et al., 2015). The jalca is critical for headwater and regional hydric balances. Native pastures (stipa ichu) and thick topsoil absorb and store water, thereby nourishing headwater lakes, wetlands, aquifers and river tributaries and springs of the quechua ecological floor (2,500-3,500 meters altitude; Buytaert \& De Bièvre, 2012). Below the jalca sur- 
face, mineral deposits with high sulfidation were formed during the Upper Cretaceous (66 million years ago) and the Paleocene (56 million years ago; Instituto Geológico, Minero y Metalúrgico [INGEMMET], 2017). Gold and copper metals are disseminated in hydrothermal mineral deposits, at a depth of approximately two kilometres underneath the jalca's surface (INGEMMET, 2017). Incipient mining in these areas dates back to pre-Hispanic and colonial periods.

The Andean hemisphere-scale conditions are affected by tectonic activities and natural 'disasters' which create dynamic conditions in watersheds and hydrological regimes. Periodic droughts, floods, landslides, hailstorms and frost have always been risks for the region's food-security. Through centuries of trial and error, technical improvement, innovation and remodelling, Andean peoples learned to thrive in the mountains. Because of environmental challenges, the primary goal of the different Andean techniques and civilizations has been to achieve sustainability in agropastoral endeavours (Valdivia, Reinoso, \& Elías, 1999). Technological innovation not only involved 'terraforming' the Andean surface to "substitute natural biodiversity with agrodiversity" (Erickson, 2018, p. 29), but also implied establishing social mechanisms of solidarity, exchange and reciprocity, as John Murra documented in the Southern Andes (Murra, 1972; van Bruen, 1996).

Ancient populations adapted to a multitude of dispersed fertile pockets, all with particular flora and fauna, depending on specific ecologies and microclimates (Murra, 1972). Steady colonization of the puna, suni and jalca from $100 \mathrm{BC}$ to $600 \mathrm{AC}$, was followed by the adoption of a general agro-pastoralism across the Andes (Lane, 2009). Economic specialization gave way to a symbiosis between full-time pastoralism in the suni, jalca and puna (from 3,500 meters altitude), and farmers in the quechua $(2,500-3,500$ meters altitude) and yunga (500-2,500 meters altitude) valleys.

From 2000 BC onwards, technological advances led to the establishment of permanent settlements. Civilizations diversified their economies, which implied settling in discontinuous hamlets next to productive areas. Field dispersal, food storage and preservation techniques, improved survival chances during bad years (Erickson, 2018). The 'vertical archipelago' settlement configuration across different ecological floors was established by autonomous groups of people with the same ancestors (ayllus; see Murra, 1972). While tapping into complementary resources across ecological floors, they established mechanisms of reciprocity within their same ethnic unit. Complementary exchange occurred between people from different ayllus. Regional interchange included goods, such as coca leaves from the yunga, tubers from the quechua as well as wool, salt and raw materials from the suni, jalca and puna. Particularly, during the Inca Empire (1440 to $1532 \mathrm{AC}$ ), there was largescale redistribution of such goods amongst different populations (Alberti \& Mayer, 1974). The footprint of these multi-scalar interrelations enlivened the territorial articulation of ecological floors.

Since $100 \mathrm{BC}$, communities of the Cajamarca Basin settled discontinuously in llaqtas (hamlets), on artificially terraced lands across jalca peaks and quechua hillsides (Reichlen \& Reichlen, 1949). The ceremonial centres of the basin's valley complemented these Ilaqtas (Watanabe, 2010). As in other Andean regions, Cajamarca's communities practised a direct and complimentary use of resource niches, along with social mechanisms of reciprocity and redistribution (Espinoza, 2018). The Qhapac Ñan and tambos facilities, administrative infrastructures of the late Inca Empire (1438-1532), were superposed on the 'vertical archipelagos' (León Ascurra \& Camargo Mareovich, 2014).

Across the region, Andean civilizations mastered various agro-pastoral and water management technologies to multiply and maintain production niches (see Figure 1). In Cajamarca, a region privileged by its semi-tropical humidity, such technologies implied the maintenance and management of headwater sources for the benefit of lower ecological floors. In the semi-arid Andes, techniques involved highland-terracing and managing water at altitudes between the yunga and puna. Qochas (artificial lakes), waru-warus (raised fields of the Altiplano), andenes (agricultural terraces) and bofedales (artificially irrigated pastures) were dominant landscape infrastructures (Kendall \& Rodríguez, 2009). These techniques were complemented by infrastructures of production (industrial workshops), storage (collcas) and communication (qhapaq ñan, or Inca roads), mostly concentrated in tambos (administrative/resting sites) and larger urban centres which accommodated passing through armies and ritual celebrations (Mumford, 2012).

The Andean communities carefully managed headwater ecosystems - their primary water source (Guillet et al., 1987). The construction of qochas provided an answer to limited water sources. They stored water during rainy seasons by building dams in natural water catchments and lining them with impermeable sediments (Lane, 2014). A cascading series of qochas transferred water from one to another, as well as to grasslands and river tributaries.

In headwater areas, the qochas supported herding pastures and habitats for wildlife and seasonal settlements. The construction of qochas also induced the appearance of bofedales, a native denomination for artificial, high-altitude moorlands with a rich plant biota eaten by camelids. Bofedales retained organic silt for geologic water storage and embodied a natural water-cleansing system (Fairley, 2003). The systemic nourishing of headwater aquifers generated and improved downstream systems that depended on groundwater (springs and wells), while simultaneously extending the limits of viable cultivation of tubers, legumes and semi-cereals to liminal areas between the quechua and the suni (or jalca).

Massive pre-Hispanic plantations of polylepis in headwater areas of suni and puna regions increased water re- 
tention (Pulgar Vidal, 1946). However, afforestation upstream went hand-in-hand with deforestation of mountainous woodlands on lower ecological floors to create agro-pastoral lands (Ellenberg, 1958). The present treeless condition of the Andes is the result of more than 10,000 years of prolonged human activities (Lynch, 1990) and their intensification during the last 500 years. Human settlement implied systematic erasure of the natural forest. As in so many contexts, the construction of new landscapes required the radical clearing of forests (Girot, 2013). The Andean settlement system persisted as dispersed, as a constellation of patches nested in particular spots, folds and other landscape pockets.
Palimpsests are usually understood as traces of previous texts, while in urbanism they are understood as remaining traces of earlier constructions. They are distinct from the new text, new development that covers the page, or the landscape (Corboz, 1983). It appears that the Andean civilizations did not entirely rewrite the landscape, but instead grafted their 'vertical archipelago' system onto the relatively few and irregularly dispersed, yet fertile pockets that subsisted after deforestation. Perhaps the palimpsest is here not so much the ruin of constructs that have become purposeless, but rather the resistant patches of fertility. Pockets of nature that withstand total and catastrophic erasure.

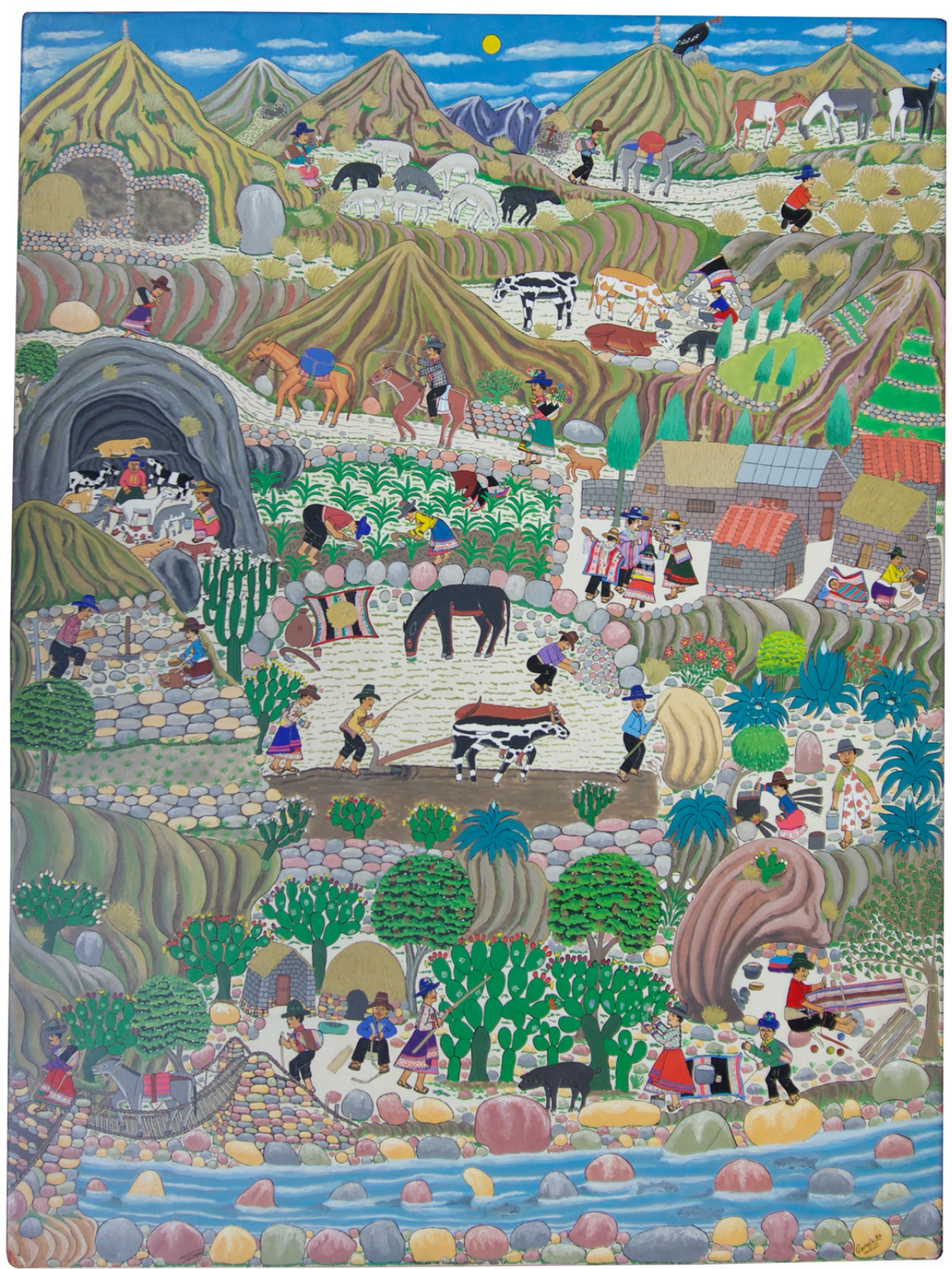

Figure 1. A painting of production niches across ecological floors in Ayacucho. In addition to productive pockets were other niches of artisanry, hunting and fishing, as well as networks of communication. The system prevails today, with new niches and programs inserted since 1532. Source: Berrocal (1995). 


\section{Historical Ruptures}

The Inca Empire restructured the territory, with infrastructure and other means, without abandoning the logics of the 'vertical archipelago'. Spanish colonization (1532-1821) enforced several waves of radical transformation as did the republic afterwards. More recent events include land reform (1969), the Shining Path's insurgency (1980-1992), and acceleration of mining activities in the wake of neo-liberal policies (1990 to today). They all are, in their own contradictory ways (reform, revolution and globalisation), reactions to the incredible social injustice that has, since Spanish colonisation, become part of the region's inescapable fate. The longue durée (Braudel, 1949) of the organic evolution of the Andean environment has been innumerably disrupted. Human dislocations, raids and retreats across different ecological floors, are amongst the direct consequences of these canonical ruptures. In parallel with the ruptures, has been the steady, yet explosive processes of urbanization and resources exploitation, in addition to the introduction of agricultural tissues in the wake of the land reform.

Between 1550 and 1580, indigenous people were relocated and concentrated in reductions, facilitating population control and labour management (Lohmann Villena, 1957). The Spanish relocation program was paralleled by the nearly total destruction of old Ilaqtas. Native productive niches and settlements were appropriated by Spanish lords. Colonial haciendas and cities were founded in privileged locations of the quechua, yunga and chala, thus replacing pre-Hispanic livelihoods. Most colonial Andean cities were superimposed on preexisting urban blocks (Mumford, 2012). Their structures were literally enmeshed as palimpsests with underlying pre-Hispanic structures -in the physical as well as social and cultural sense. New regime rules (as forced labour) paralleled surviving dynamics of reciprocity. Cities, haciendas, reductions and mining enclaves defined new settlement constellations.

At the same time, Conquest wars, non-native epidemic diseases and human exploitation caused massive demise of indigenous peoples during the early Spanish regime. In the Peruvian Andes, the population fell from about 9 million in 1520 to 600,000 in 1620 (Newson, 1993). The population was moreover confined to living in reductions, Catholic missions or mining compounds. Violent processes of depopulation and dislocation produced a massive-scale abandonment of landscape infrastructures (Tello, 1921). The interruption of water-table nourishment caused a general water decline, which led to the retreat from multiple unsupplied andenes.

The occupation of suni, jalca and puna's mineral niches by colonial enterprises expelled Andean peoples from headwater areas. Mines displaced seasonal agro-pastoral settlements, as well as headwater sources for mineral processing and human consumption (see Figure 2). Demands of fuel (for metallurgy) and wood (for mine girders and urban constructions) incited massive deforestation in headwater areas (Kessler, 1995), thereby reducing their water-retention capacity. Nonetheless, mining settlements developed and grew despite the inhospitable conditions of the suni, jalca and puna for permanent human occupation. They typically developed with neither sufficient planning nor structural investment. Colonial mining was all about extraction and export. The development of a qualitative environment was never on the agenda. Not surprisingly, it began as a predatory, ex- and appropriation of indigenous settlements and resources. After an interruption during the independence wars, mineral extraction in the headwaters resumed. A number of colonial mines were taken over by foreign and Peruvian mining companies (Aramayo Bazzetti \& Sanchez Infantas, 2010), while artisanal mining activities reclaimed other old shafts.

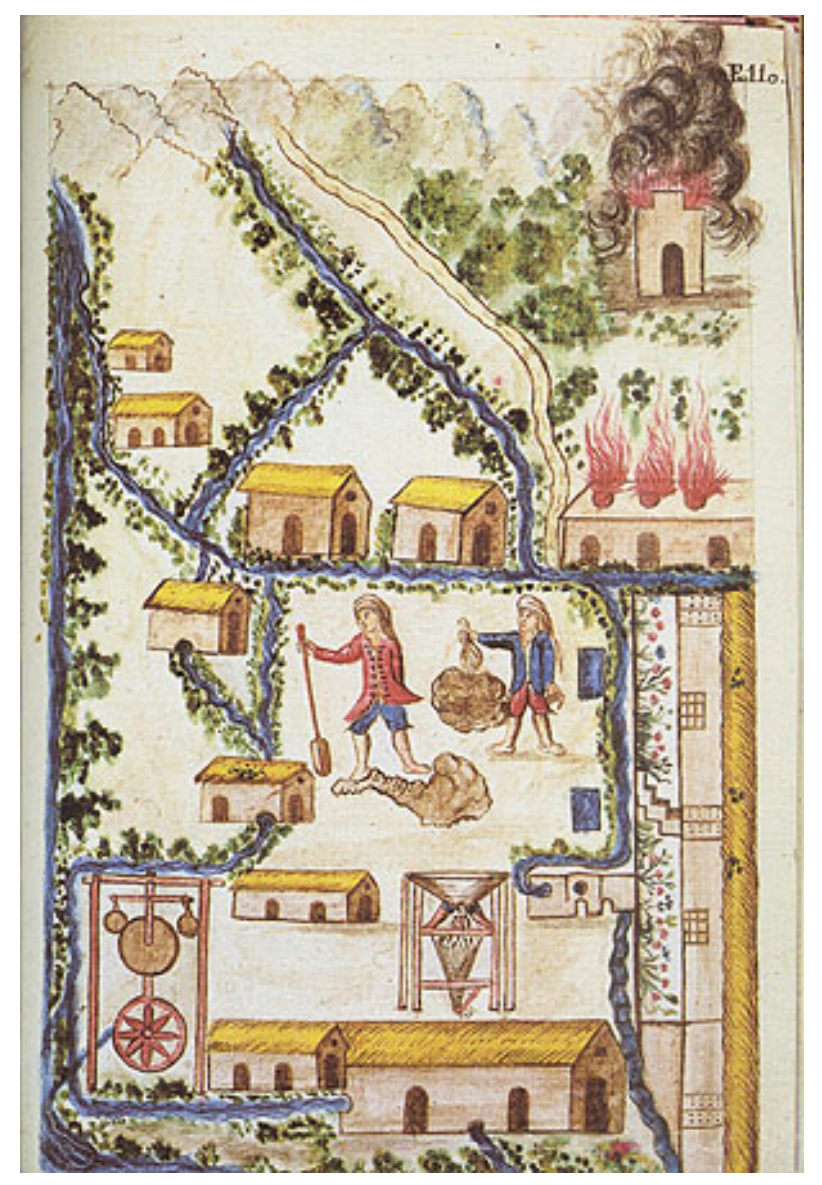

Figure 2. In 18th century Cajamarca, mining operations implied the canalisation of headwater sources for mineral processing and the burning of native vegetation for fuel. Source: Martínez Compañón (1936/2015).

After independence (1821), Spanish descendants intruded on community lands to expand their haciendas. This new wave of dispossession and reclusion to less fertile areas forced peasants to over-exploit fields, become hacienda's servants or simply migrate to cities. By 1950, permanent confrontations between hacendados 
and peasants, as well as rising urban and rural poverty, culminated in simultaneous waves of peasant insurgencies throughout the country. In 1969, reform sought to re-structure the nation's land tenure system. Coastal plantations and semi-feudal haciendas in the highlands were expropriated and redistributed. By 1979, more than nine million hectares were returned to 370,000 beneficiaries (Eguren, 2006).

With few exceptions, colonial settlements took over almost all pre-Hispanic sites of Cajamarca. After indigenous resettlements in the Chota, Cutervo and Santa Cruz reductions (1551 to 1578), vacant Ilaqtas and productive lands were converted into haciendas (Espinoza, 2018). Urban structures of Cajamarca's colonial city replaced Inca ceremonial facilities and squares located in the western foothills of the valley (Mumford, 2012), and in the floodplain believed to have once been an ancient lake (von Humboldt, 1850). Simultaneously, caseríos emerged around new colonial agglomerations, most of which prevail until today (see Figure 3 ). Indigenous reductions became towns, and dismantled haciendas (after the land reform) were subdivided into multiple (large) productive plots.

For centuries, Cajamarca's jalca was part of the region's agro-pastoral and water management (Young, 1988). In Cumbemayo (the southwest jalca of the basin), a 7,600 meters-long pre-Hispanic canal conveyed water from headwater pastures to downstream settlements. The abundance of headwater sources enabled the existence of a large-scale, but fine-mazed irrigation system, as well as a considerable amount of springs (in mountainous areas) and wetlands (in the lowlands; see Figure 4).
However, during the colonial era, haciendas owners intensively herded ovine in the jalca and over-consumed headwater resources.

In the early 1900s, cattle and dairy production in haciendas became the foundation of Cajamarca's economy; herding occurred in irrigable lands. In 1947, Nestlé's dairy production was situated in the region and rapidly increased areas of herding grasslands. The increase of pastures continued despite implementation of the Peruvian Land Reform. However, given new plot subdivisions, the industry shifted towards a decentralised model of supply from small-land holders.

Seasonal herding also re-colonized the jalca and dispersed Andean settlements were re-established adjacent to headwater lakes. Between 1953 and 1989, local communities reproduced Cumbemayo's canalization model in the headwaters of the Grande River. A series of canals were constructed in the basin, tapping water from tributaries to irrigate valley pastures. As a sequence of development waves, the reoccupation of headwaters and mountainous areas by dispersed settlements reactivated traditional systems, erased the colonial impositions and undid appropriations of large landowners.

Yearly burning practices in the jalca allowed fresh ichu for grazing to grow while preventing other vegetal species from colonizing the highlands. Until 1993, dense ichu vegetation covered $77 \%$ and dispersed ichu vegetation accounted for $16 \%$ of the basin's jalca (Palacios \& Lundberg, 2006). In the liminal areas between the quechua and jalca ecological floors, nests of wildlife around rocky areas coexisted with crops. Only limited extraction of raw materials occurred. Headwater communi-

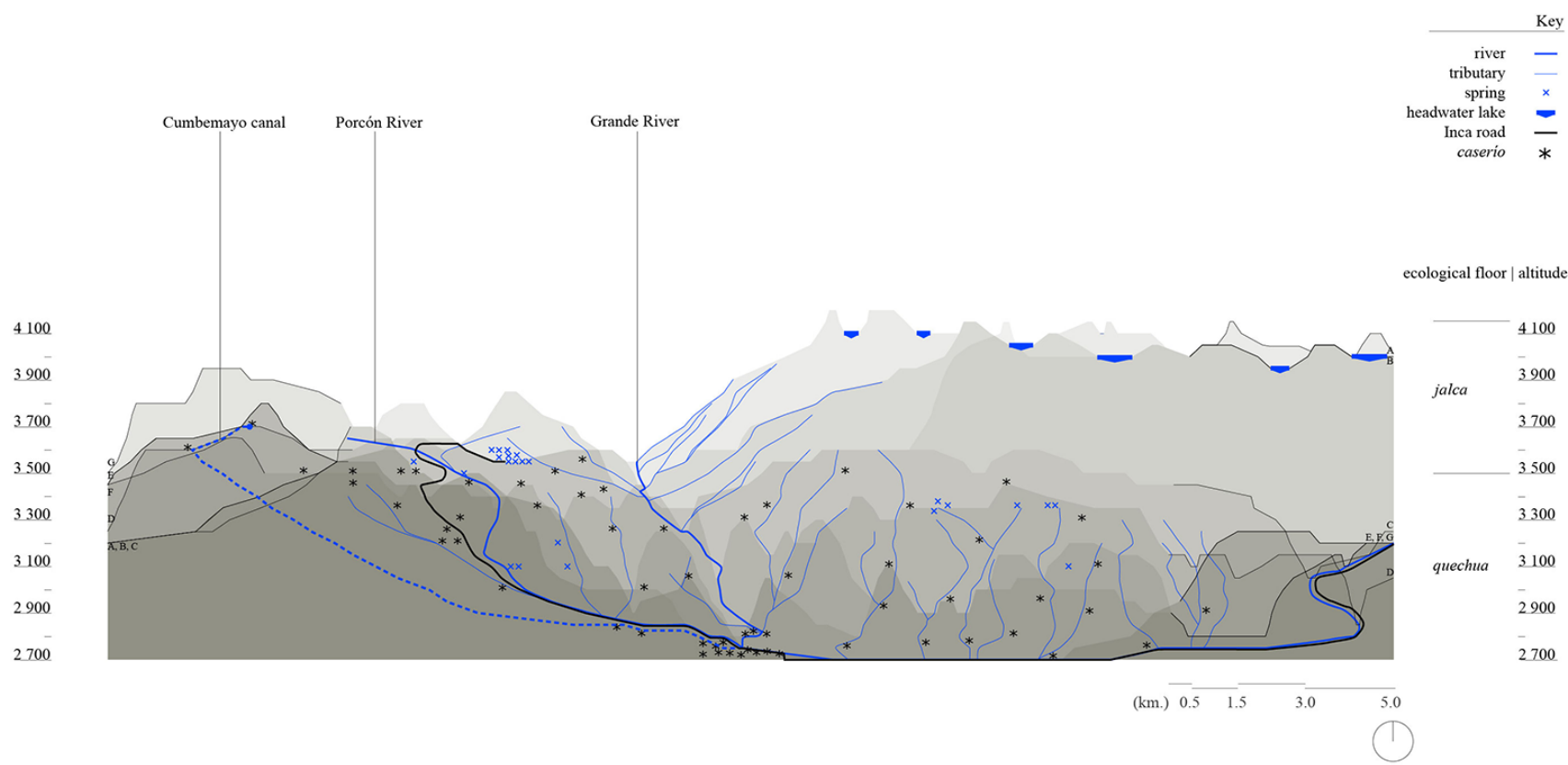

Figure 3. The self-subsistence economies of caseríos in the Cajamarca basin are articulated by a hydrological network of headwater lakes, springs and streams. Human agglomerations only began to occur in the basin's floodplains after the establishment of the colonial Villa of Cajamarca. Sources: Elaborated by Margarita Macera, based on database from Gobierno Regional de Cajamarca (2015) and CGIAR-CSI Consortium for Spatial Information (2015, Version 4). 


\section{COGITATIO}

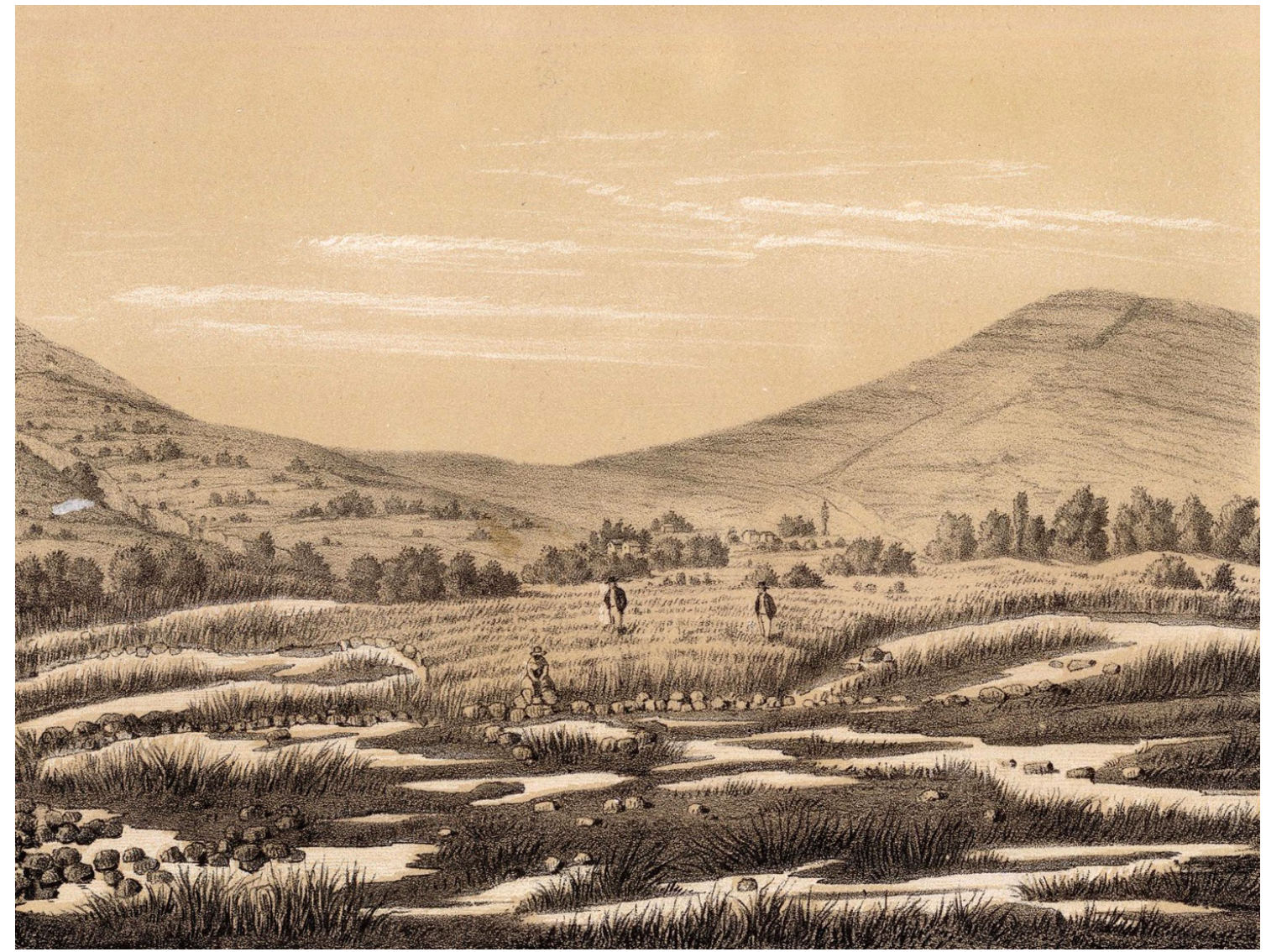

Figure 4. Foraging and dispersed housing occurred in the basin's lowlands, once an ancient lake. Urbanisation and agropastoral activities in the area caused a progressive drying of the territory. Source: Paz Soldán (1865b).

ties retrieved mud for the construction of adobes (mudbricks) and used pasture hatch for the construction of roofs and mattresses, as medicine and domestic fuel or, eventually, as a commercial supply for urban brick factories (Palacios \& Lundberg, 2006).

The Andean peasants welcomed the redistribution of land brought by the land reform. At the same time, they heavily resisted reform's push for the commercial-based logics of the single-crop. Extensive agriculture is contrary to the nature of indigenous traditions. It targeted, some would say in the best colonial tradition, export markets rather than regional needs. Not surprisingly, the induced modernization processes increased rural poverty in the Peruvian Andes, as sadly illustrated by (infant) mortality rates (McClintock, 1984). For many peasant communities, the rise of the Shining Path (1980) was an inevitable act of rebellion against centuries of oppression (Ron, 2001). The violent iteration of action and reaction it catalysed induced massive retreat from rural livelihoods and an accelerated migration towards cities. During the early 1990 s, the country's pacification resulted in a favourable investment climate.

Since 1992, new neoliberal policies stimulated investment of multinational large-scale mining companies in headwater areas (Bury, 2005). Modern mining in the Andes uses the latest available technologies for multimetallic exploitation. A more substantial capacity of ex- cavation, a hydro-metallurgy and automated processing technologies have allowed for 'world-class' resource extraction (Randolph, 2011). However, these newer techniques require more water usage and cause increased environmental damage-the costs of which are externalized. Since a substantial part of the country's tax income is obtained from mining, land concessions (through forced expropriation) and privileged access to headwater sources are easily granted to mining enterprises. It strikingly resonates with centuries of old colonial policy and its legitimization. The rural poor endure the brunt of this newest wave of expropriation and their livelihoods dwindle. After being expelled to the unhospitable mountains and headwaters during colonialism, local communities are now pushed out of the headwaters and into the informal urban realm.

Complicating matters further, water has become highly contested (Budds \& Hinojosa-Valencia, 2012). Regional hydric stress is not only a consequence of the intensive use of water for metallurgy. Hydric pressures also stem from Peru's rapid urban growth and the tangible effects of climate change (Buytaert \& De Bièvre, 2012). Unsustainable mining and urbanization combined with rapid deglaciation and uneven rainfall patterns in Andean headwaters have driven the region into a 21st century hydric emergency. Farming communities inhabiting the unhospitable foothills and mountain 
slopes, where they have historically been both pushed to and driven out of, are squeezed between the water hungry mining sites in the headwaters and cities in the valleys.

The Cajamarca Basin circumscribes Cajamarca city and includes a series of dispersed mountainous settlements, and the goldmines of Yanacocha (see Figure 5). Yanacocha's surface mines overlap with the basin's north- ern jalca and the tributaries (and upstream canals) of the Grande River. New techniques to optimize ore extraction from dispersed ore-containing soils allow profitable mining in the jalca, previously considered a 'marginal' site. The first exploration in the jalcas was led by France's Bureau de Recherches Géologiques et Minières in 1970 (Palacios \& Lundberg, 2006). In 1983, the multi-national mining companies, Newmont S.A and Buenaventura, in-

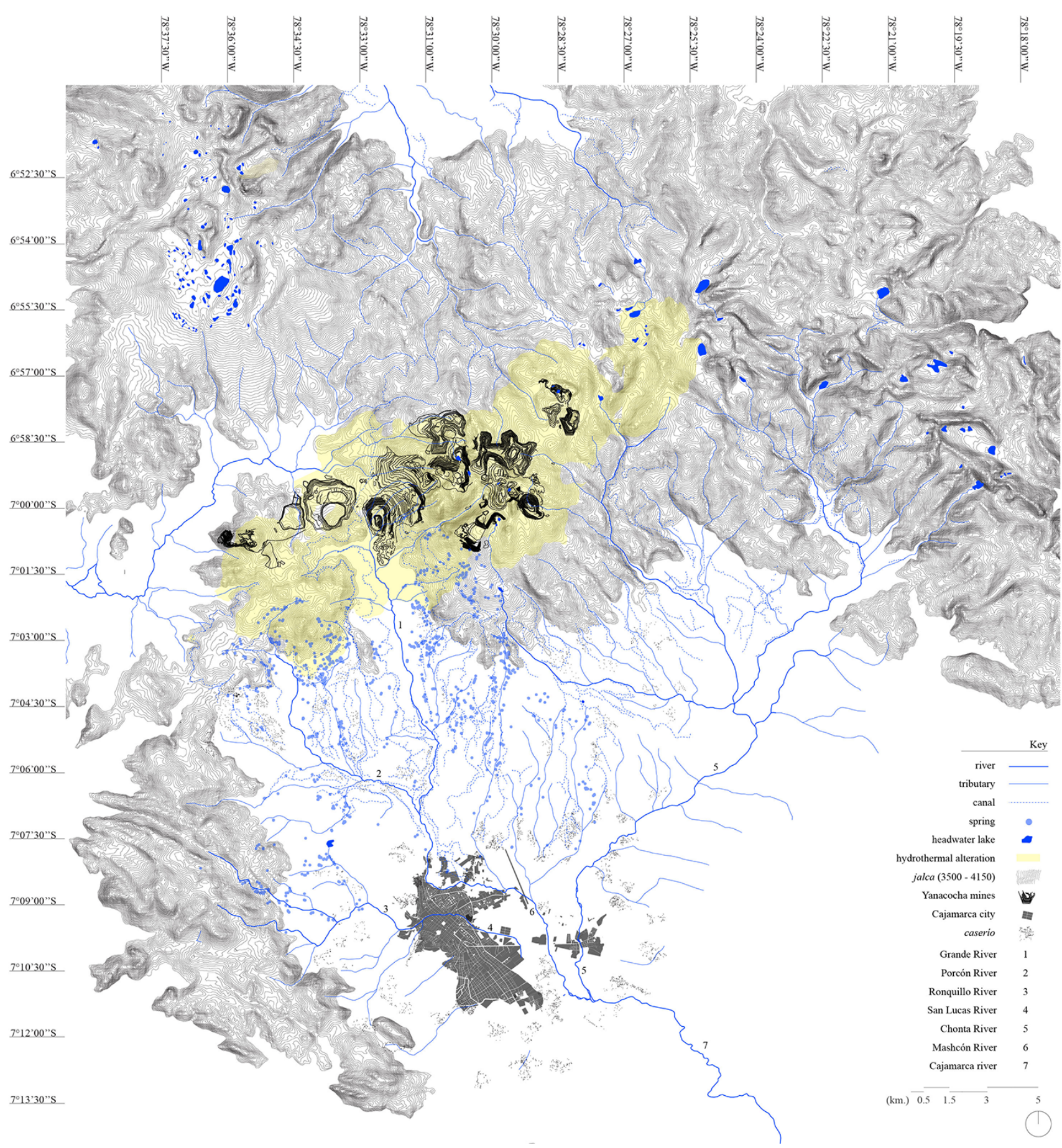

Figure 5. Water in the Cajamarca Basin is an element of contestation and articulation between mining, urban and rural ecologies. The mining compound's strategic location monopolises large-scale mechanisms of water management. Sources: Elaborated by Margarita Macera, based on database from Gobierno Regional de Cajamarca (2015), CGIAR-CSI Consortium for Spatial Information (2015, Version 4) and Google Earth. 


\section{COGITATIO}

tensified prospecting (see Figure 6). In 1993, Cajamarca became the first site of large-scale modern mining in the Peruvian Andes. The Yanacocha mines, $40 \mathrm{~km}$ north of the city, have had sequential phases of exploitation, expansion and temporary inactivity (see Figure 7). With mining plans being continuously updated, there is no precise date for the compound's final closure. Yanacocha went through a first productive cycle from 1994-2001. In 2001-2007, mining operations expanded towards the fluvial deposits of La Quinua, upstream of the Grande River. In 2008, the construction of a gold mill to process higher-grade ores facilitated the extension of mining operations until 2015, 2023 and then 2027. As well, already in 2006, mineral exploration indicated the pres-
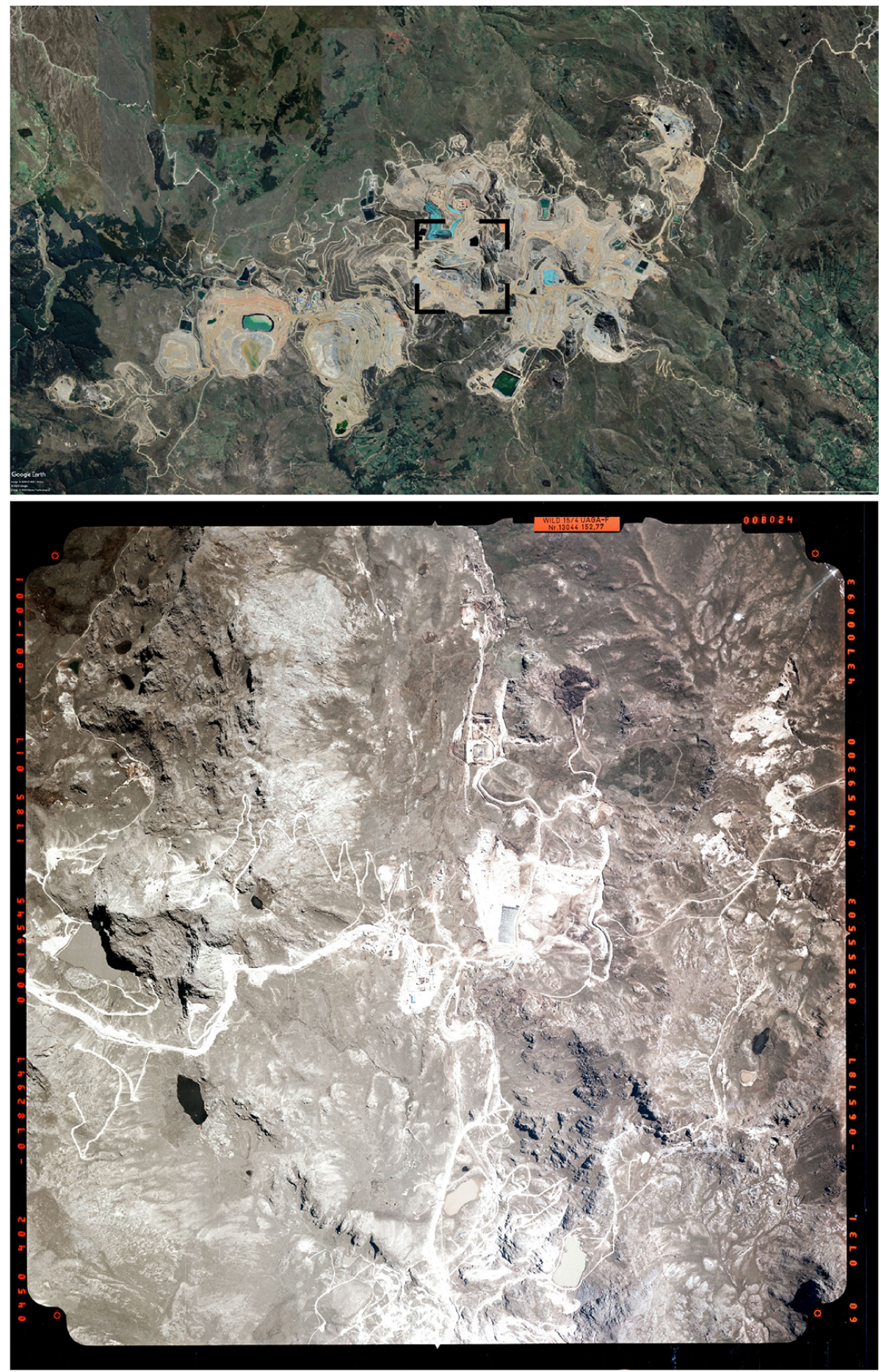

Figure 6. Mining prospections of 1983 took place next to Yanacocha Lake (upper aerial photograph). Pedestrian infrastructures intertwined with new roads for vehicles, headwater lakes, rocky surfaces and hummocks. The morphology of this landscape is unrecognisable after 37 years of mining activities (lower aerial photograph). Sources: Servicio Aerofotográfico Nacional (1983) and Google Earth. 
1993

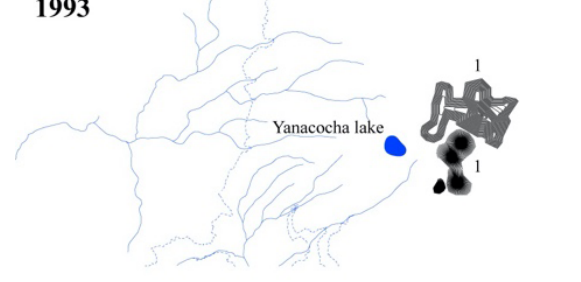

1995
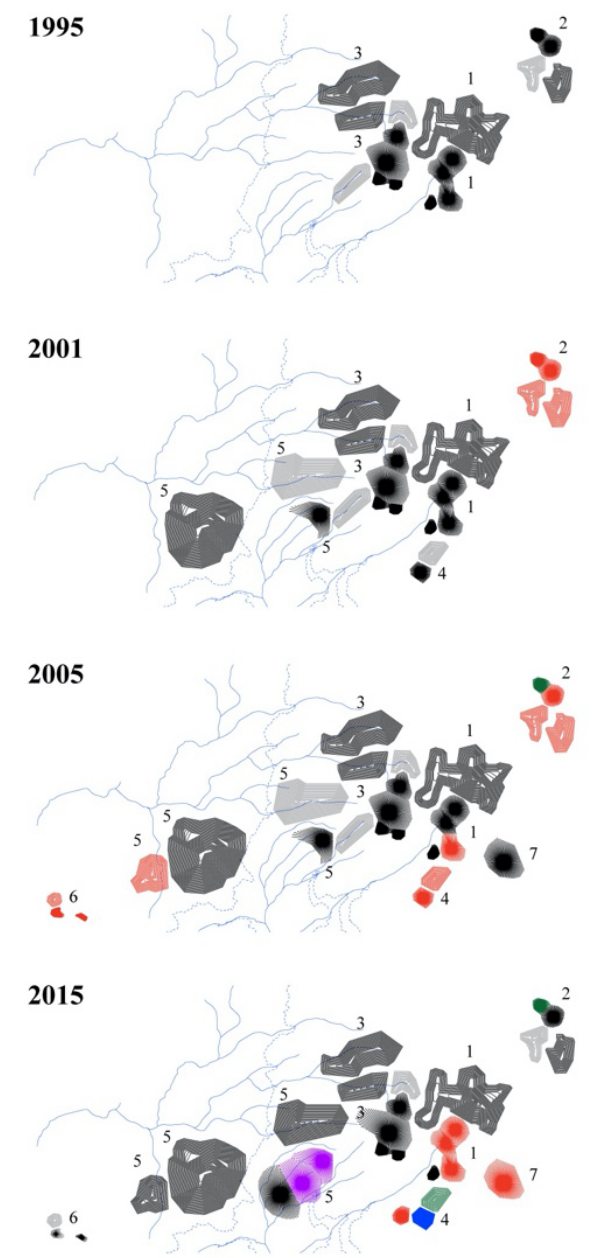
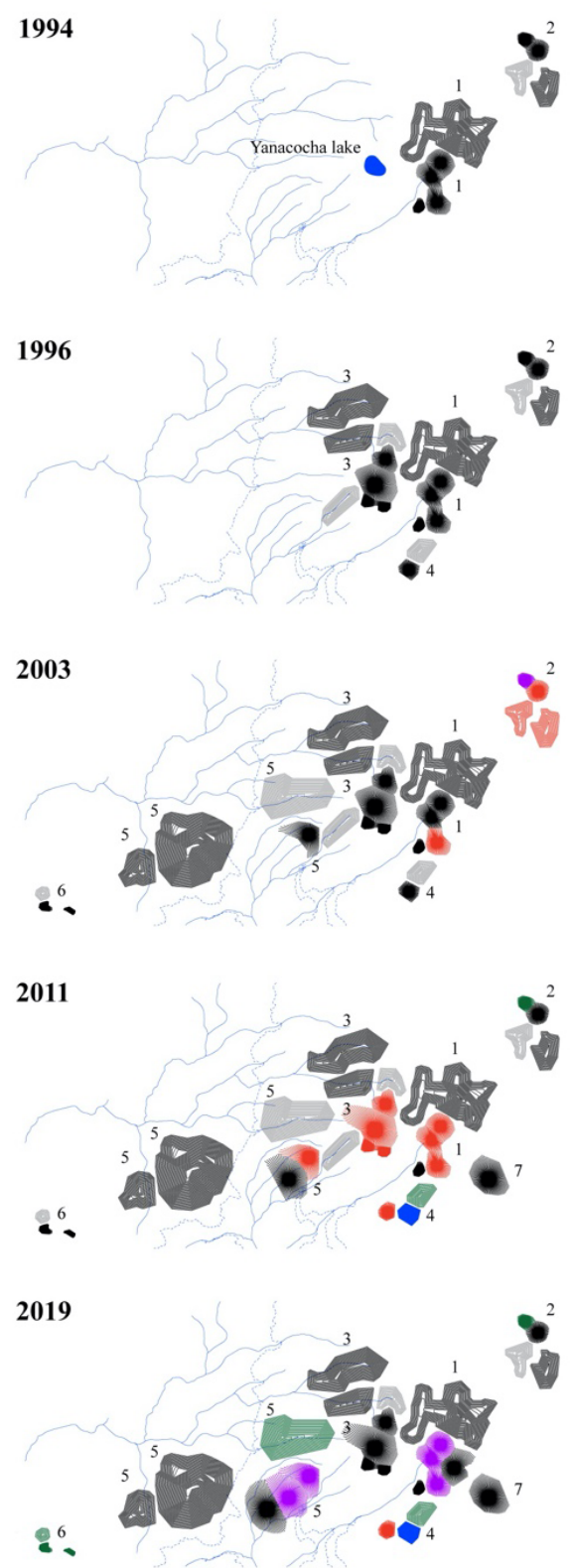

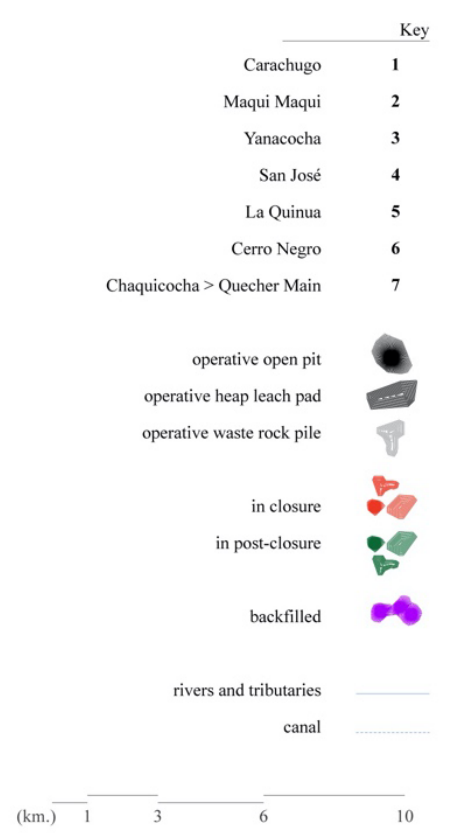

Figure 7. Yanacocha's mining (1993-2019) reveals iterative phases of exploration, exploitation and (temporary) closure occur in the different mining units. Sources: Elaborated by Margarita Macera, based on database from Gobierno Regional de Cajamarca (2015), Google Earth, Ministerio de Energía y Minas (2018) and MYSRL (2006, 2010).

ence of copper underneath gold-bearing deposits (Teal \& Benavides, 2010), meaning a second wave of exploitation would be possible after gold deposits were exhausted.

Over the last twenty years, socio-environmental conflicts have increasingly halted the execution of mining expansion plans within the Minera Yanacocha S.R.L. (MYSRL) concession boundaries and also outside of them. Therefore, due to the difficulty of operating in new areas, MYSRL expanded its mining operations deeper within already operative sites. In 2023, the Quecher Main project is slated to begin operation and will be located in the existing footprint of the Chaquicocha open-pit. Quecher Main will exploit of the remaining oxide ores (gold) of the pit and expand to subjacent sulphide deposits (of copper; see Ministerio de Energía y Minas, 2018). This new project will stretch the mining cycle until 2039. In this sense, mining is becoming a more cyclic endeavour, catalysing a continuous wave of exploitation. 
Nonetheless, in legal and planning terms, mining remains a linear operation: prospection, investment, exploitation, closure, and environmental repair.

Cajamarca's existing urban infrastructure facilitated mining operations. The region's mining did not require large investment in general infrastructure. Therefore, it is not surprising that the Yanacocha mine-which expropriated local communities in the headwaters and claimed the precious water sources-was contested from the beginning. The sequence of making, undoing, remaking, undoing and the repeated alteration of local and external development modes are quite remarkable. The resulting landscape occupies a particular place in palimpsest cases.

\section{5. (Post)Mining Cajamarca}

\subsection{Transformation of Landscape-Ecologies by Mining}

Goldmining activities in Yanacocha involve the excavation of open pits and the construction of haul roads, heap-leach pads and waste-rock piles. In addition to the mobilisation of earth, cyanide water flows allow for the processing and capture of gold. Through drip-irrigation, the massive heap-leach pads are infused with a constant flow of cyanide and water to distil ores into a rich solution, which then flows to a leaching pond (Trexler, Flynn, \& Hendrix, 1990). From this pond, gold-cyanide solutions flow to the ore-processing plants where ores are smelted into doré (gold and silver) bars. The remaining solution subsequently loops back to the top of the heap for further rinsing. Cyanide, acid mine drainage (AMD) and freshwater flows are articulated by new water infrastructures (ponds, pipes, canals and treatment plants), intertwined with pre-existing canals and river tributaries.

Yanacocha's "low waste-to-ore strip ratios" (Teal \& Benavides, 2010, p. 1174) sustain an accommodation of large volumes of soil in leach pads. While open pits reach depths of more than 300 meters, leach pads can be 100 meters in height. The design and planning of mining facilities answers to cost-efficient transportation and storage of ore-containing soils, as well as to the access of underground mineral deposits. The construction of new mountains and cavities are the collateral damage of mining. They significantly alter the hydric performance of jalca. New artificial water infrastructure creates new watersheds and fundamentally restructures the water management mechanisms in headwaters and ecologies of the basin (see Figure 8).

Yanacocha's mining excavations remove more than 70,000 tons of material daily (Ingetec S.R.L., 2003). They strip the jalca's ancient topsoil, and disturb ichu pastures wetlands, lakes, river tributaries and upstream canals. Until its depletion, the old Yanacocha Lake was a primary water source. Since its demise, rainwater storage and recycling systems have been installed (MYSRL, 2006). At the same time, aquifers are pumped from open pits to keep them workable. To mitigate downstream water scarcity and pollution, AMD is treated, and the cleansed water is discharged into river tributaries. The mines and settlements of the Cajamarca Basin compete for the same locational resource, namely the local and larger water systems (Bridge, 2004). In an increasing number of cases over the past three decades, socio-

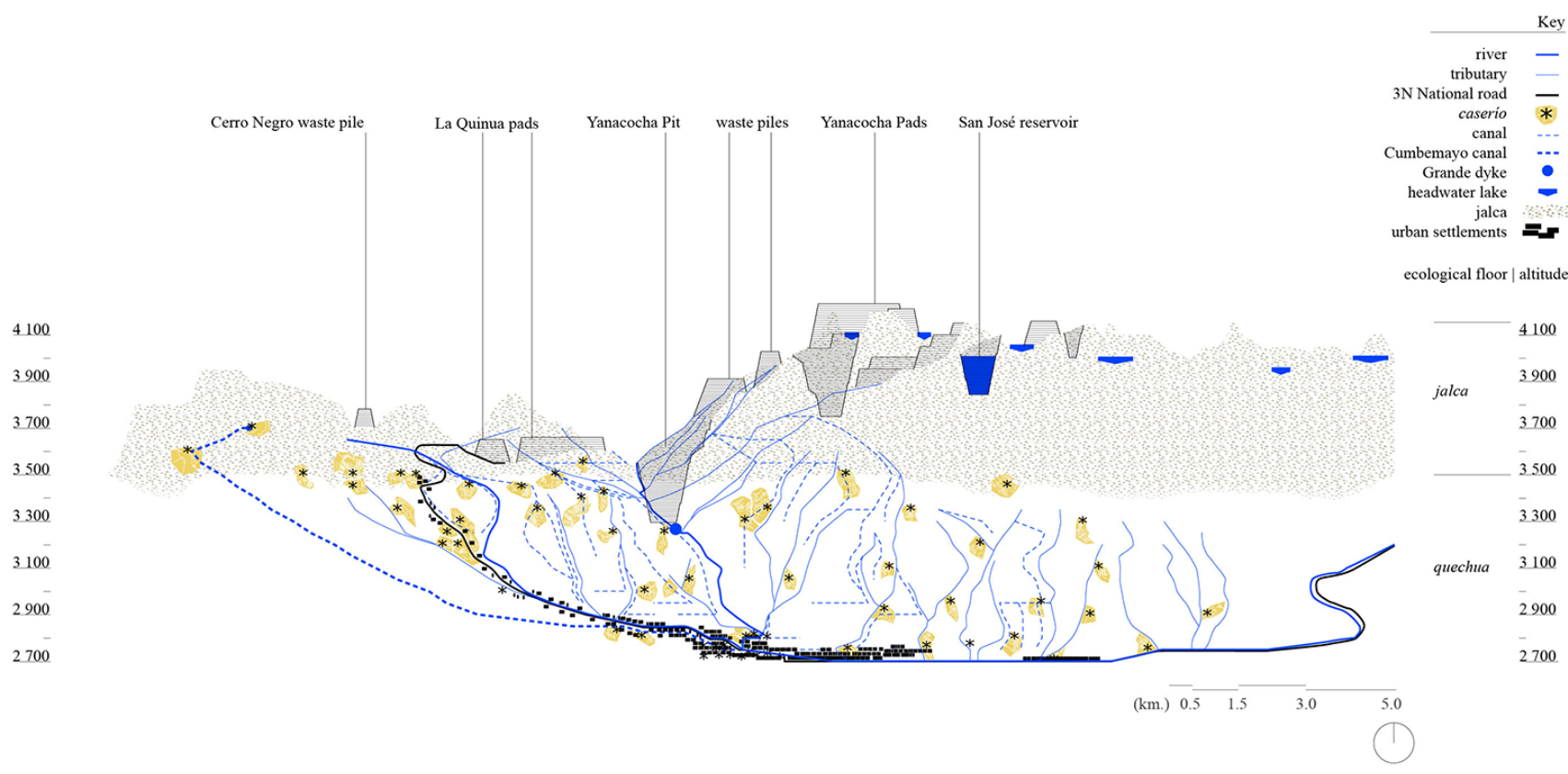

Figure 8. Historically, the basin-scale mechanisms of water included provision by canals and springs, both which depended upon the nourishment of headwater aquifers. Today, rural areas rely on the discharge of treated water and distribution networks from the San José Reservoir. Water consumption in the city relies on the regulated flows coming from the Grande River Dike. Sources: Elaborated by Margarita Macera based on database from Gobierno Regional de Cajamarca (2015), CGIAR-CSI Consortium for Spatial Information (2015, Version 4) and Google Earth. 
environmental conflicts around water and land have challenged business-as-usual. Today, mining companies have to demonstrate expertise in water management.

Peruvian law requires the monitoring of Yanacocha's detrimental water use. The mining company is required to regulate upstream water quality and quantity, and to develop basin-scale water provision for downstream livelihoods (see Figure 9). In 2004, the company took over the construction of the Grande River Dike to regulate sediment discharge and increase urban water supply. The measure doubled the regular production of the city's potable water (Empresa Prestadora de Servicio de Agua Potable y Alcantarillado Sanitario de Cajamarca, 2019). However, the hard-engineered system breaks away from the traditional water paradigm in the Andes, where water supply comes from a multitude of sources and springs in the basin.
To compensate for the damage of upstream canals, and the loss in water flows from groundwater-dependent springs, the company constructed family water reservoirs in rural areas. However, these measures are insufficient to meet the increasing hydric demands of downstream populations, which have grown as a result of mining (Instituto Nacional de Estadística e Informática, 2017).

\subsection{Post-Mining Interventions}

Yanacocha's ongoing mining procedures occur in parallel to activities of progressive mining closure (see Figure 10). Although local communities have the legal right to validate post-mining visions, the mining closure activities todate have been realized unilaterally. The imminent mining closure will leave not only a socio-environmental cri-

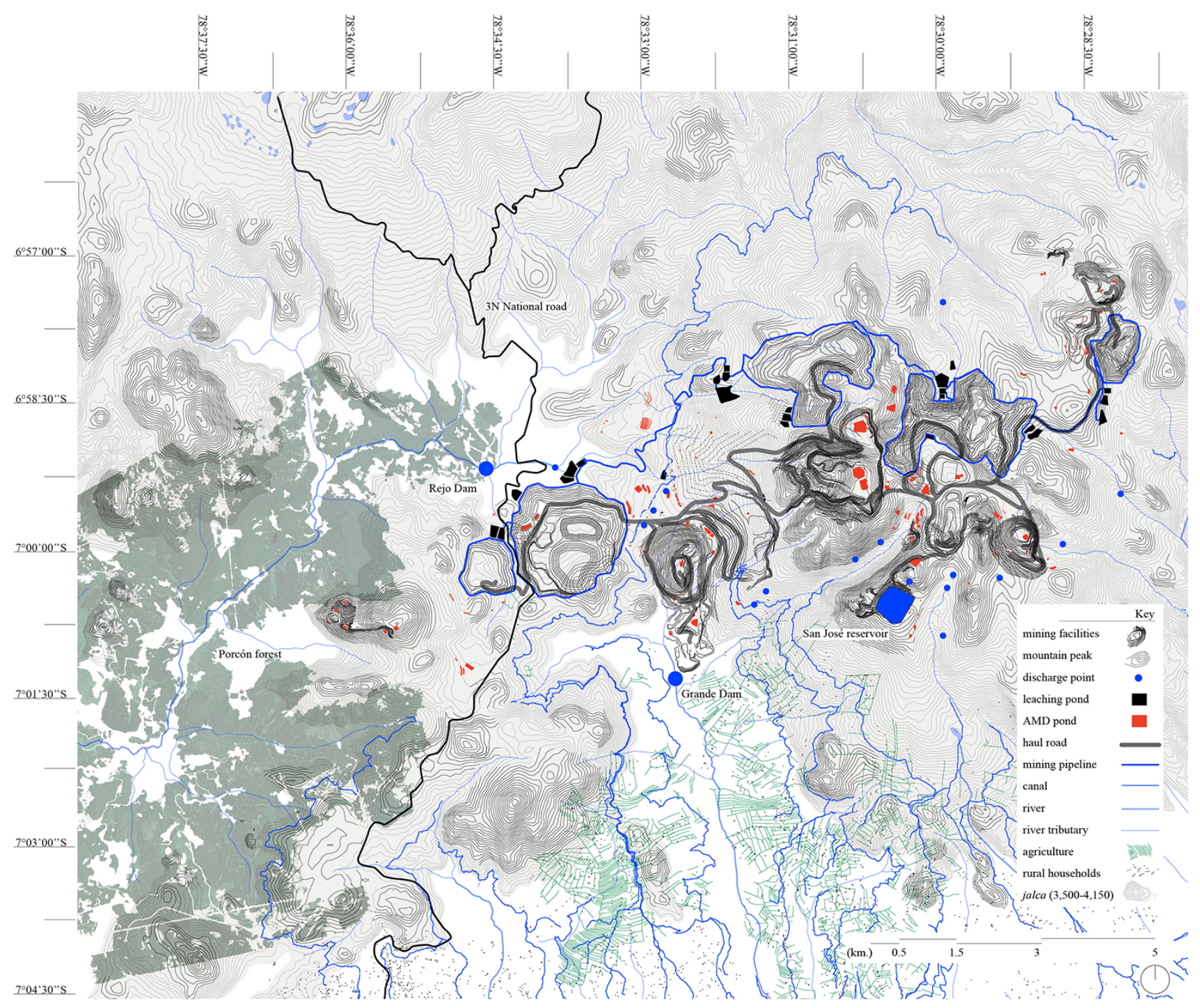

Figure 9. In Cajamarca's headwaters, the infrastructures of mining (pits, pads, waste-piles, pipes, ponds, dikes, haul roads) intertwine with remaining canals, lakes and mountain peaks. Meanwhile, downstream agriculture and forestry expand towards higher altitudes. Sources: Elaborated by Margarita Macera, based on database from Gobierno Regional de Cajamarca (2015), CGIAR-CSI Consortium for Spatial Information (2015, Version 4), Google Earth, MYSRL (2006), Teal and Benavides (2010), Vela-Almeida, Kuijk, Wyseure, and Kosoy (2016) and Yacoub López (2007). 


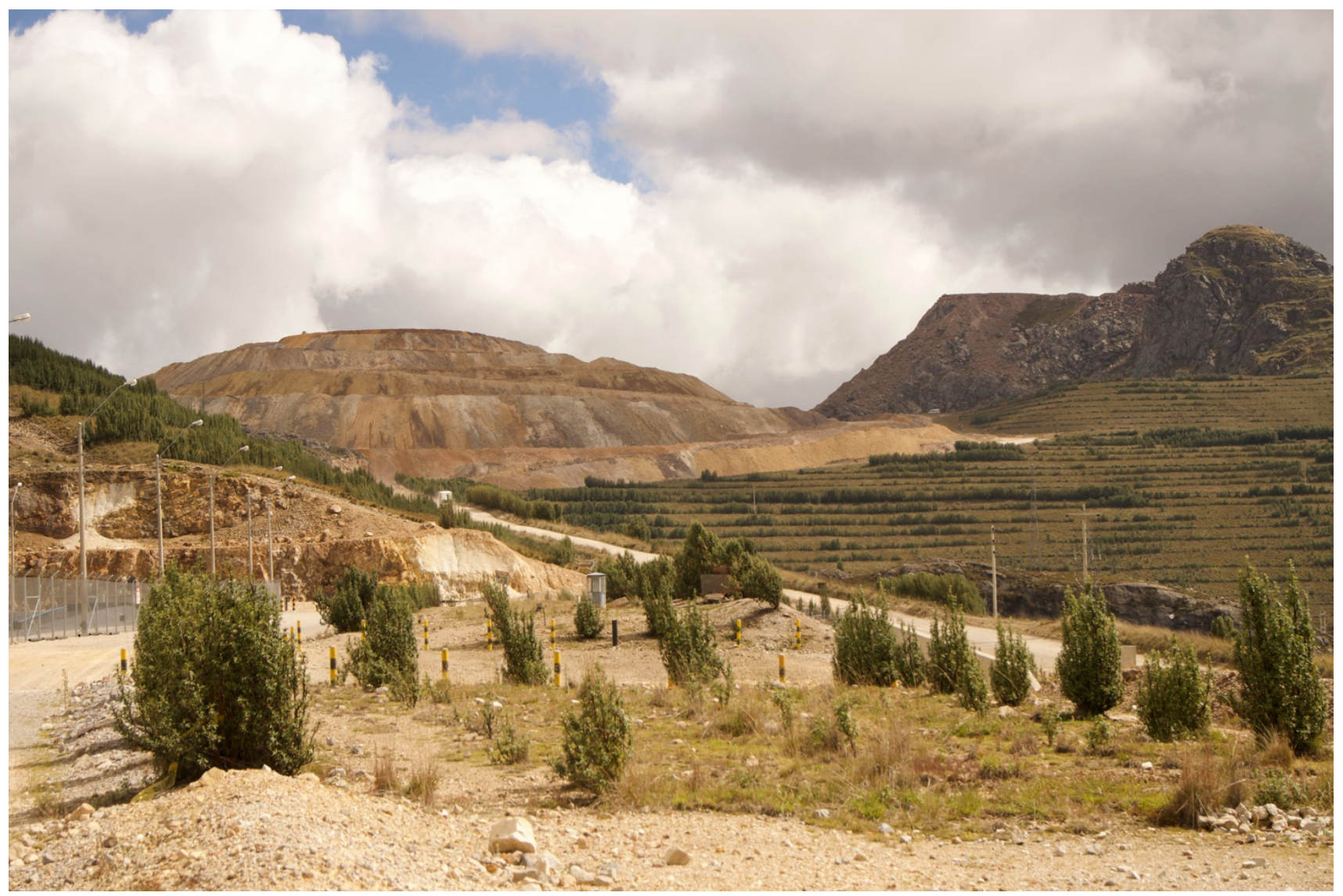

Figure 10. In 2018, the higher altitudes in Maqui Maqui bear witness to disturbed, remediated and remnant jalca landscapes. Pre-existing and revegetated patches of stipa ichu and polylepis intertwine with rocky hummocks and rock-waste piles. Modern mining, post-mining and ancient headwater ecologies coexist in space and time. Source: Photography by Margarita Macera.

sis, but as well an economic one without precedent. It is not evident that the disastrous impact of mining on the territory's soil, vegetal and hydrological regimes can ever again become self-sustainable and non-hazardous. In order to guarantee safe freshwater provision, it will be necessary to install perennial water treatment mechanisms after mining closure (MYSRL, 2012). To this end, the company will need to maintain custody of the disturbed headwater sites. However, perpetual headwater management and water supply service by MYSRL poses a threat to the long-term stability of Cajamarca's water governance. MYSRL's reduced financial capital will undoubtedly become an excuse for passing on the post-mining water management costs to the population. MYSRL's 'responsible mining' policies are unlikely to ease the scepticism of communities that, de facto, will inevitably bear the costs of post-mining remediation or the consequences of the lack of remediation.

Progressive closure procedures are carried out when mineral resources are exhausted, or mining heaps have reached maximum storage capacity. Mitigating the effects of AMD is a priority with regards to environmental protection (Younger, Banwart, \& Hedin, 2002). There are standard environmental engineering protocols to isolate AMD sources, re-contour slopes and cover them with new top-soil (Burley, 2001; MYSRL, 2019; see Figure 11). Re-vegetation aims to trigger processes of natural succession and re-colonisation by native species (Bradshaw, 2000). In Yanacocha, most progressive mining closure procedures start from default spatial configurations (dictated by the geometry of open pits, pads and waste piles), focusing on mitigating the ecological hazards of mining landforms (Tongway \& Ludwig, 2011).

Other types of post-mining intervention include the re-programming of remediated areas. In 2000, a partial backfilling occurred in Yanacocha's Maqui Maqui Pit. Since 2006, the Mining Closure Experimental Centre has operated on the pit's re-contoured surface, in parallel to a continuous treatment of AMD effluents, monitoring and maintenance of the rehabilitated areas (MYSRL, 2007). Maqui Maqui includes a nursery for post-mining revegetation and alpaca farmyards. In 2005, other mining closure activities involved the re-contouring, overlining and flooding of the San José Pit, to turn it into a 6 million cubic meters capacity water reservoir. Since 2007, it has stored treated runoff water of mining facilities for ore processing and the feeding of upstream canals (that once fed directly from multiple headwater sources; MYSRL, 2008). The transformation of the pitas in the case of the Grande River Dyke-centralises wa- 


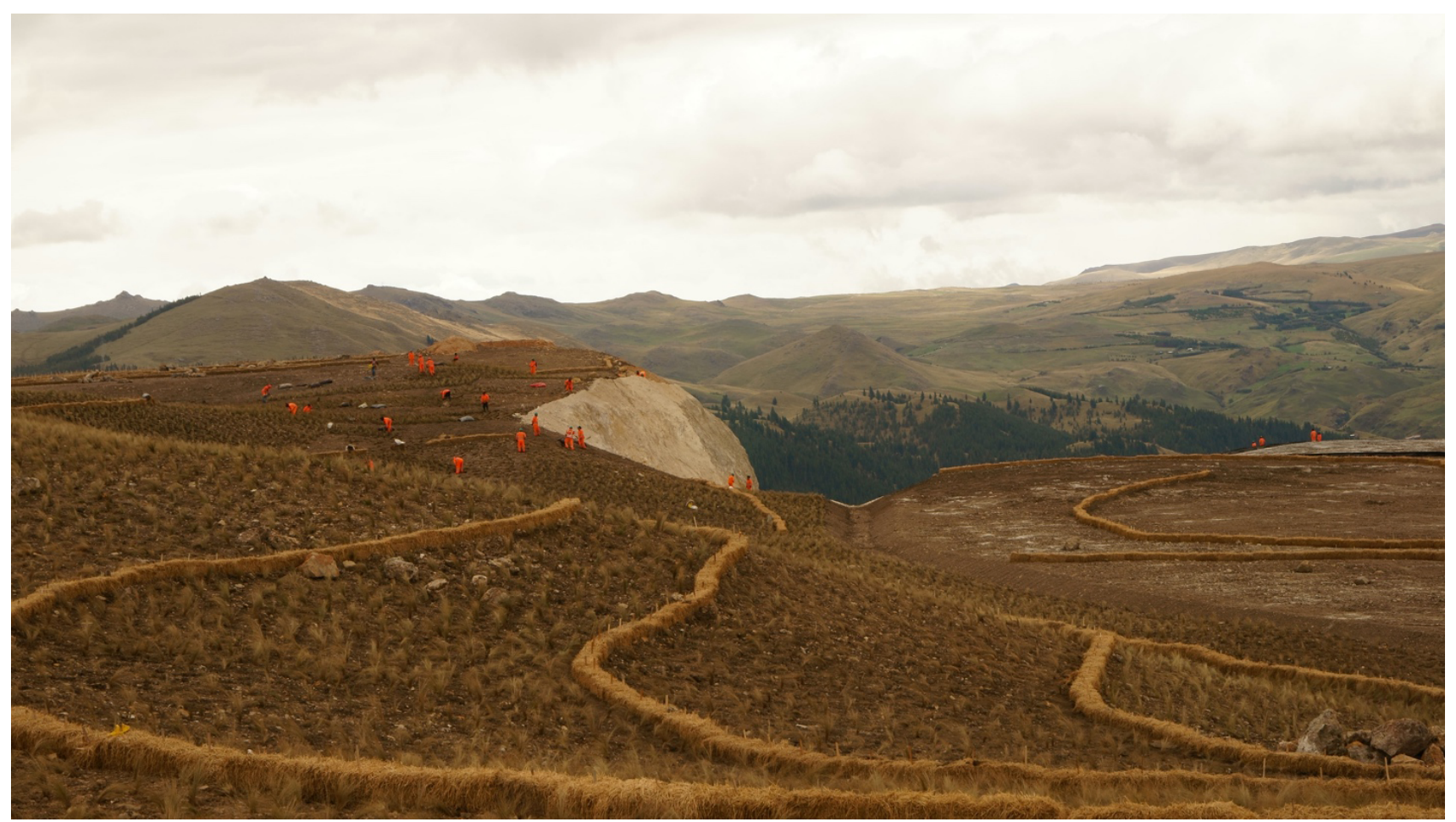

Figure 11. In 2015, excavated materials from La Quinua pit served to re-contour its adjacent north rock waste piles while expanding operations south, towards the headwaters of the Grande River. The measures involved revegetation of the area with native pastures and mimicking the surrounding environment. Source: Photography by Margarita Macera.

ter provision through large-scale water treatment and collection. With the extinction of former headwater sources, secure water provision for downstream rural populations now relies on the continuous maintenance of such infrastructures.

Compared to the large capital investment capacity of mining, closure procedures have economic and operational limitations. Exceptionally, progressive rehabilitation processes benefit from mining's earthmoving machinery to execute plans of large-scale "topographic reconstruction" (Toy \& Chuse, 2005, p. 30). Other than the stabilisation of slopes and landscape revegetation, no explicit landscape architecture strategy is applied in the relocation of excavated soils. Artificial, centralised water collection, treatment and distribution mechanisms disguise ecological disturbances of the postmining landscapes. The integration of landscape, infrastructure and water management protocols to local, downstream socio-ecologies of the Cajamarca Basin remains uncertain. Mimicking the site's former topography and vegetation are certainly not sufficient measures to integrate post-mining landscapes into a selfrenewable environment.

The definitive cessation of Yanacocha's mining will intensify existing socio-environmental contestations. Therefore, a shift in reclamation methods is critical. It is no longer possible to wait for the end of mining activities in order to begin to re-shape the voluminous, hazardous, disturbed landscapes and ecologies. A post-mining vision must be developed immediately in order to initiate post-mining remediation activities that can substantially restore self-renewing hydrological regimes. Cajamarca requires the design of its future headwater landscapes, which includes the planning of mining activities themselves. Clearly, mining resources (financial and logistic) can be instrumental for the construction of transitional (post-mining) landscapes, where water flows can be progressively redirected and cleansed (Athanasiou, 2018; see Figure 12).

An alternative post-mining scenario proposes to recharge headwater aquifers and restore an overall 'sponginess' to the jalca. In this way, the ecological floors (and settlements) below Cajamarca's jalca can benefit from clean water. The strategy gradually converts Yanacocha's mining facilities into performative landscape infrastructures for water harvesting, retention and redistribution (Athanasiou, 2018). It proposes that haul road networks progressively become spines for water management. These networks can isolate clean runoff from polluted effluents, accommodate passive AMD cleansing systems (constructed bofedales), and guide clean water flows towards new irrigation systems that intertwine with pre-existing ones. While providing water for downstream communities, the new irrigation system also functions as new tributaries in the Grande River catchment. At the same time, the construction of qochas and polilepys forests in strategic catchment areas can guarantee minimum baseflows to nourish both surface (canals and river tributaries) and aquifer-dependant (springs) water bodies. 


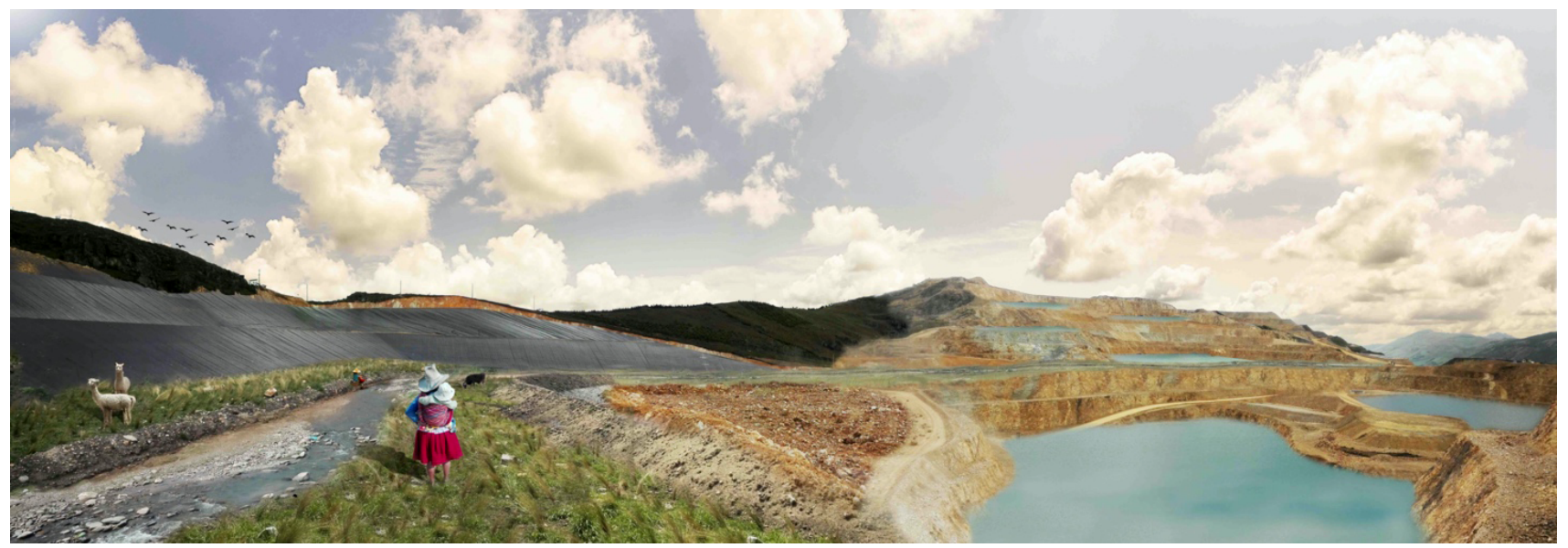

Figure 12. An alternative scenario for the transitional landscapes of La Quinua open pit in 2025 envisions to orchestrate ongoing earth works for the formation of new water flows and catchments. Constructed wetlands clean water before its distribution in downstream canals. Source: Athanasiou (2018).

The proposal builds on indigenous landscape infrastructure logics which can be rationalised, eventually upscaled and re-build Cajamarca's future ecologies. The focus on desirable future scenarios could re-direct local stakeholder's contentious discussions towards a shared post-mining vision, assuming that MYSRL can be motivated (or forced by government bodies and pressure from civil society, local and international NGOs, etc.) towards co-produced process of vision development.

In the context of Cajamarca's goldmining, interpretative mapping visualised the contested spatial, social and environmental dynamics within and beyond the confines of the MYSRL compound. The historical reading of Cajamarca and the Andes' long-term landscape evolution contextualised landscape transformations within broader, cyclic, systematic processes of socio-ecological disturbance-particularly the decimation of the jalca landscape by mining (from 1993 to 2020). Exploring the interactions between the longue durée of Cajamarca and the present, transitional mining landscapes of its jalca can better inform design strategies for post-mining development. Such a methodological approach can be applied to other contexts of large-scale, surface, mining of the broader Andean region.

\section{Conclusion: (Post)mining Landscape Palimpsests}

Historical continuums and ruptures-from geological to human scales-have made the Andes a palimpsest of landscape transformations. The rise and fall of indigenous and colonial civilizations have been fundamental to the overlapping processes of settlement and abandonment of Andean habitats. Among these processes, the modern mining of the neoliberal era is the latest sequel of successive waves of headwater colonization.

North Andean palimpsests follow new territorial logics over-writing old ones while preserving enduring structures. Colonial land structures coexist with ancient relations of reciprocity across ecological floors. Reformed rural land structures exist alongside sparse, but prevailing, pre-Hispanic productive pockets and urban niches (Mumford, 2012). Reductions over-wrote pre-Hispanic livelihoods, retained a substantial Andean population and became towns. Despite being colonial products, Andean towns, caseríos and cities are part of today's prevailing 'vertical archipelago.' As colonial products, they have been appropriated and taken over by local cultures. The reversal of meanings is one of the interesting, often re-occurring operations that palimpsests evince (Corboz, 1983). Indigenous techniques subsist for an extremely long time, next to predominantly colonial and modern landscape infrastructures. The resilience of indigenous landscape infrastructures is explained by their robust, but adaptative response, over centuries, to dynamic Andean environmental conditions.

In the last fifty years, an interplay of technological development and a never-satisfied market-driven gold hunger has magnified the impact of mining enterprises on the Andean headwaters. Automated modern mining technologies threaten to compromise future hydric balances of local and regional Andean ecologies. Postmining scenarios consequently have not only to take the disrupted headwater areas into account, but also the entire water basin.

Cajamarca's future post-mining development demands looking back to deeply understand-and learn from-its palimpsest landscape dynamics. These dynamics can shed light on the critical headwaters attributes to restore and the techniques to do so. Although the exact reconstruction of the jalca environment is unrealistic, restoring its performance is a long-term possibility. Pre-Hispanic techniques of earth-formation and water management can induce water retention in soil and self-water-cleansing mechanisms in headwater areas. Rationalising, adapting and upscaling these techniques is a priority. If timely used, modern mining can then bring the tools to 're-naturalize' landforms in an efficient manner. While implementing this design-construction 
method, beneficial, transitional landscapes (and new landscape palimpsests) can be intentional rather than accidentally created.

\section{Acknowledgments}

We would like to thank the Department of Architecture, Faculty of Engineering Science (KU Leuven, Belgium) and research centre Centro de Competencias del Agua (Ayacucho, Peru) for funding fieldwork trips to Cajamarca. We would also like to acknowledge Minera Yanacocha S.R.L. and Compañía de Minas Buenaventura for facilitating access to the region's mines. Finally, we would also like to recognize the design research contribution of losif Athanasiou, a 2018 graduate of the Master of Urbanism and Strategic Planning program at KU Leuven.

\section{Conflict of Interests}

The authors declare no conflict of interests.

\section{References}

Alberti, G., \& Mayer, E. (1974). Reciprocidad andina: Ayer y hoy [Andean reciprocity: Yesterday and today]. In G. Alberti \& E. Mayer (Eds.), Reciprocidad e intercambio en los Andes peruanos [Reciprocity and exchange in the Peruvian Andes] (pp. 13-36). Lima: Instituto de Estudios Peruanos.

Aramayo Bazzetti, A., \& Sanchez Infantas, E. (2010). Determining collapse phases in the different stages of the environmental history evolution of Cerro De Pasco (1901-2008). Ecología Aplicada, 9(2), 113-124.

Athanasiou, I. (2018). Territorial sponge and battery. Reclaiming headwaters in a disfigured landscape (Unpublished Master's thesis). Faculty of Engineering Science, KU Leuven University, Leuven.

Berrocal, C. (1995). Sarhua, actividades cotidanas [Sarhua, everyday activities; Painting]. Lima: Collection Macera Carnero, Banco Central de Reserva del Perú.

Bradshaw, A. (2000). The use of natural processes in reclamation: Advantages and difficulties. Landscape and Urban Planning, 51(2/4), 89-100.

Braudel, F. (1949). The Mediterranean and the Mediterranean world in the age of Philip II (Vol.1). Oakland, CA: University of California Press.

Bridge, G. (2004). Contested terrain: Mining and the environment. Annual Review of Environment and Resources, 29, 205-259.

Budds, J., \& Hinojosa-Valencia, L. (2012). Las industrias extractivas y los paisajes hídricos en transición en los países andinos: Análisis de la gobernanza de recursos y formación de territorios en Perú [Extractive industries and water landscapes in transition in Andean countries: Analysis of resource governance and territorial formation in Peru]. In R. Boelens \& F. Peña
(Eds.), Agua, Injusticia y Conflictos [Water, injustice and conflicts]. Lima: Editorial CBC and IEP.

Burley, J. B. (Ed.). (2001). Environmental design for reclaiming surface mines. Lewiston, NY: Edwin Mellen Press.

Bury, J. (2005). Mining mountains: Neoliberalism, land tenure, livelihoods, and the new Peruvian mining industry in Cajamarca. Environment and Planning $A$, 37(2), 221-239.

Buytaert, W., \& De Bièvre, B. (2012). Water for cities: The impact of climate change and demographic growth in the tropical Andes. Water Resources Research, 48(8), $1-13$.

CGIAR-CSI Consortium for Spatial Information. (2015). SRTM Data 90m DEM [Geo Tiff dataset]. Retrieved from http://srtm.csi.cgiar.org/srtmdata

Corboz, A. (1983). The land as palimpsest. Diogenes, 31(121), 12-34.

Eguren, F. (2006). Reforma agraria y desarrollo rural en el Perú [Land reform and rural development in Peru]. Lima: Editorial Centro Peruano de Estudios Sociales.

Ellenberg, H. (1958). Wald oder Steppe? Die natürliche Pflanzendecke de Anden Perus, I [Forest or steppe? The natural plant cover of Andean Peru, I]. Die Umschau in Wissenschaft und Technik, 21, 645-648.

Erickson, C. L. (2018). The domesticated landscapes of the Andes. In L. Seligmann \& K. S. Fine-Dare (Eds.), The Andean world (pp. 29-43). New York, NY: Routledge.

Espinoza, W. (2018). Miradas etnohistoricas a Cajamarca [Ethno-historical views of Cajamarca]. In H. Quiroz \& P. J. Pazos (Eds.). Lima: Universidad Nacional Mayor de San Marcos.

Fairley, J. P. (2003). Geologic water storage in Precolumbian Peru. Latin American Antiquity, 14(2), 193-206.

Galán de Mera, A., Sánchez-vega, I., Montoya Quino, J., Linares Perea, E., Campos de la Cruz, J., \& Vicente Orellana, J. A. (2015). La vegetación del norte del Perú: de los bosques a la Jalca en Cajamarca [The vegetation of northern Peru: From the forests to the jalca of Cajamarca]. Acta Botanica Malacitana, 40, 157-190.

Girot, C. (2013). Immanent landscape. Harvard Design Magazine, 36, 6-16. Retrieved from http:// www.harvarddesignmagazine.org/issues/36/ immanent-landscape

Gobierno Regional de Cajamarca. (2015). Shapefiles proceso de zonificación ecológica y económica: Ordenamiento territorial [Shapefiles ecological and economic zoning process: Territorial management]. Gobierno Regional de Cajamarca. Retrieved from http:// sigr.regioncajamarca.gob.pe

Guillet, D., Browman, D. L., D’Altroy, T. N., Hunt, R. C., Knapp, G. W., Lynch, T. F., . . . Treacy, J. (1987). Terracing and irrigation in the Peruvian highlands [and comments and reply]. Current Anthropology, 28(4), 409-430. 
Instituto Nacional de Estadística e Informática. (2017). Perú: Crecimiento y distribucion de la población [Peru: Population's growth and distribution]. Lima: Instituto Nacional de Estadística e Informática. Retrieved from https://www.inei.gob.pe/media/MenuRecursivo/ publicaciones_digitales/Est/Lib1530/libro.pdf

Ingetec S.R.L. (2003). Auditoría ambiental y evaluaciones ambientales de las operaciones de la Minera Yanacocha en Cajamarca-Perú [Environmental audit and environmental evaluations of the operations of Minera Yanacocha in Cajamarca-Peru]. Cajamarca: Ingetec S.R.L.

Instituto Geológico, Minero y Metalúrgico. (2017). Mapa metalogenético del Perú [Metallogenetic Map of Peru]. Lima: Instituto Geológico, Minero y Metalúrgico.

Kendall, A., \& Rodríguez, A. (2009). Desarrollo y perspectivas de los sistemas de andenería de los Andes centrales del Perú [Development and perspectives of the andenes systems in the Peruvian central Andes]. Lima: Institut français d'études andines.

Kessler, M. (1995). Present and potential distribution of Polylepis (Rosaceae) forests in Bolivia. In S. P. Churchill, H. Balslev, E. Forero, \& J. L. Luteyn (Eds.), Biodiversity and conservation of neotropical montane forests (pp. 281-294). Bronx, NY: New York Botanical Garden.

Lane, K. (2009). Engineered highlands: The social organization of water in the ancient north-central Andes (AD 1000-1480). World Archaeology, 41(1), 169-190.

Lane, K. (2014). Water technology in the Andes. In H. Selin (Ed.), Encyclopaedia of the history of science, technology, and medicine in non-Western cultures. Dordrecht: Springer.

León Ascurra, W. J., \& Camargo Mareovich, C. (2014). Camino Inca Cajamarca-Baños del Inca [Inca Road Cajamarca-Baños del Inca]. Lima: Ministerio de Cultura.

Lohmann Villena, G. (1957). El corregidor de indios en el Perú bajo los Austrias [The corregidor of Indians in Peru under the Habsburgs]. Madrid: Ediciones Cultura Hispánica.

Lynch, T. F. (1990). Quaternary climate, environment, and the human occupation of the south-central Andes. Geoarchaeology, 5(3), 199-228.

Martínez Compañón, B. (2015). Repasiles repasando en Buitrón y cargando Azogue [Mining workers carrying quicksilver; Painting]. In Trujillo del Peru (Vol. II). Alicante: Biblioteca Virtual Miguel de Cervantes. (Original work published 1936). Retrieved from http://www.cervantesvirtual.com/obra-visor/ trujillo-del-peru-V-volumen-ii/html/966bf129a181-4dd1-996b-ac44db7844e2_117.html

McClintock, C. (1984). Why peasants rebel: The case of Peru's Sendero Luminoso. World Politics, 37(1), 48-84.

Minera Yanacocha S.R.L. (2006). Estudio de impacto ambiental proyecto suplementario Yanacocha
Oeste. Resumen ejecutivo [Environmental impact study supplementary project West Yanacocha. Executive summary]. Lima: Minera Yanacocha S.R.L. Retrieved from http://www.minem.gob.pe/minem/ archivos/file/DGAAM/estudios/yanacocha/oeste/ yana_oeste.htm

Minera Yanacocha S.R.L. (2007). Centro experimental para el cierre de minas 'Maqui Maqui' [Experimental centre of mining closure 'Maqui Maqui']. Lima: Minera Yanacocha S.R.L. Retrieved from https://www. snmpe.org.pe/repositorio-premio-al-desarollosostenible/80-2007/4290-centro-experimental-parael-cierre-de-minas-maqui-maqui.html

Minera Yanacocha S.R.L. (2008). Reservorio San José [San Jose reservoir]. Lima: Minera Yanacocha S.R.L. Retrieved from http://www.yanacocha.com/wpcontent/uploads/Reservorio-San-Jose.pdf

Minera Yanacocha S.R.L. (2010). Actualización del plan de cierre de minas para las instalaciones de Minera Yanacocha. Resumen ejecutivo [Update of the mine closure plan for the Minera Yanacocha S.R.L. facilities. Executive summary]. Lima: Minera Yanacocha S.R.L.

Minera Yanacocha S.R.L. (2012). Tercera modificación del plan de cierre de minas de minera Yanacocha correspondiente a la segunda modificación del EIA Proyecto Cerro Negro. Resumen ejecutivo [Third modification of the mining closure plan of Yanacocha mining company corresponding to the second modification of Cerro Negro project's environmental impact study. Executive summary]. Lima: Minera Yanacocha S.R.L.

Minera Yanacocha S.R.L. (2019). Cierre técnico [Technical closure]. Lima: Minera Yanacocha S.R.L. Retrieved from http://www.yanacocha.com/1-cierre-tecnico

Ministerio de Energía y Minas. (2018). Perú: Cartera de proyectos de construcción de mina 2018 [Peru: Portfolio of mine construction projects 2018]. Lima: Ministerio de Energía y Minas.

Montgomery, D. R., Balco, G., \& Willett, S. D. (2017). Climate, tectonics, and the morphology of the Andes. Geology, 29(7), 579-582.

Mumford, R. J. (2012). Vertical empire. The general resettlement of Indians in the colonial Andes. London and Durham, NC: Duke University Press.

Murra, J. (1972). El 'control vertical' de un máximo de pisos ecológicos en la economía de las sociedades andinas ['Vertical control' of a maximum of ecological floors in the economy of andean societies]. Huánuco: Universidad Nacional Hermilio Vardizán.

Newson, L. A. (1993). The demographic collapse of native peoples of the Americas, 1492-1650. Proceedings of the British Academy, 81, 247-288.

Palacios, H., \& Lundberg, A. (2006). Análisis del cambio de paisaje en un área minera del Perú: Caso estudio de Yanacocha, Cajamarca [Landscape change analysis in a mining area of Peru: Case study of Yanacocha, Cajamarca]. Espacio y Desarrollo, 18, 117-144.

Paz Soldán, M. F. (1865a). Cuadro general de alturas 
comparativas del Perú [General table of comparative heights of Peru; Atlas Map]. Paris: Librería de Augusto Durand, David Rumsey Historical Map Collection. Retrieved from https://www.davidrumsey. com/luna/servlet/s/18g69s

Paz Soldán, M. F. (1865b). Aguas termales, Cajamarca [Thermal waters, Cajamarca; Llitographed view]. Paris: Librería de Augusto Durand, David Rumsey Historical Map Collection. Retrieved from https://www. davidrumsey.com/luna/servlet/s/037cb6

Pulgar Vidal, J. (1946). Historia y geografía del Perú: Las ocho regiones naturales del Perú [History and geography of Peru: The eight natural regions of Peru] (1st ed.). Lima: Universidad Nacional Mayor de San Marcos.

Pulgar Vidal, J. (1996). Geografía del Perú: Las ocho regiones naturales, la regionalización transversal, la sabiduría ecológica tradicional [Geography of Peru: The eight natural regions, transversal regionalisation, traditional ecological wisdom] (10th ed.). Lima: Peisa.

Purser, M., \& Purser, W. F. C. (1971). Metal-mining in Peru, past and present. New York, NY: Praeger Publishers.

Randolph, M. (2011). Current trends in mining. In P. Darling (Ed.), SME mining engineering handbook (3rd ed., pp. 11-19). Englewood, CO: Society for Mining, Metallurgy, and Exploration.

Reichlen, H., \& Reichlen, P. (1949). Recherches archéologiques dans les Andes de Cajamarca: Premier rapport de la mission ethnologique Française au Perou Septentrional [Archaeological research in the Andes of Cajamarca: First report of the French ethnological mission in Northern Peru]. Journal de La Société des Américanistes, 38, 137-174.

Ron, J. (2001). Ideology in context: Explaining Sendero Luminoso's tactical escalation. Journal of Peace Research, 38(5), 569-592.

Empresa Prestadora de Servicio de Agua Potable y Alcantarillado Sanitario de Cajamarca. (2019). Plan maestro optimizado quinquenio 2019-2023 [Fiveyears optimized master plan 2019-2023]. Cajamarca: SEDACAJ. Retrieved from http://www.sunass.gob. pe/websunass/index.php/eps/estudios-tarifarios/ planes-maestros-optimizados-pmo/doc_details/ 3387-eps-sedacaj-s-a-pmo-2019-2023

Servicio Aerofotográfico Nacional. (1983). Vista aérea de Yanacocha [Aerial view of Yanacocha]. Lima: Fuerza Aérea del Perú.

Teal, L., \& Benavides, A. (2010). History and geologic overview of the Yanacocha mining district, Cajamarca, Peru. Economic Geology. Bulletin of the Society of Economic Geologists, 105(7), 1173-1190.

Tello, J. C. (1921). Introducción a la historia antigua del Perú [Introduction to the ancient history of Peru]. Lima: Editorial Euforion.

Tongway, D., \& Ludwig, J. (2011). Restoring disturbed landscapes. Putting principles into practice. Washington, DC: Island Press.
Tosi, J. A. (1960). Zonas de vida natural en el Perú: Memoria explicativa sobre el mapa ecológico del Perú [Natural life zones in Peru: Explanatory memory of the ecological map of Peru] (Vol. 5). Lima: Instituto Interamericano de Ciencias Agrícolas de la OEA, Zona Andina.

Toy, T. J., \& Chuse, W. R. (2005). Topographic reconstruction: A geomorphic approach. Ecological Engineering, 24(1/2), 29-35.

Trexler, D. T., Flynn, T., \& Hendrix, J. L. (1990). Heap leaching. Geo-Heat Center Quaterly Bulletin, 12(4), 1-4.

Troll, C. (1962). Die dreidimensionale Landschaftsgliederung der Erde [The three-dimensional landscape structure of the earth]. Bonn: Geographisches Institut der Universität Bonn.

Valdivia, R. F., Reinoso, J. R., \& Elías, B. M. (1999). Descripción y evaluación de un sistema de qochas en la cuenca norte del Titicaca [Description and evaluation of a qocha system in the northern Titicaca basin]. Gaceta Arqueológica Andina, 25, 147-166.

van Bruen, M. (1996). Rethinking the vertical archipelago: Ethnicity, exchange and history in the south central Andes. American Anthropologist, 98(2), 338-351.

Vela-Almeida, D., Kuijk, F., Wyseure, G., \& Kosoy, N. (2016). Lessons from Yanacocha: Assessing mining impacts on hydrological systems and water distribution in the Cajamarca region, Peru. Water International, 41(3), 426-446.

von Humboldt, A. (1805). Geographie des plantes equinoxiales [Geography of equinoctial plants]. Paris: Langlois, David Rumsey Historical Map Collection. Retrieved from https://www.davidrumsey.com/luna/ servlet/s/cea3a0

von Humboldt, A. (1850). Views of nature: Or contemplations on the sublime phenomena of creation with scientific illustrations. London: Harrison and Sons.

Watanabe, S. (2010). Continuidad cultural y elementos foráneos en Cajamarca, sierra norte del Perú: El caso del Horizonte Medio [Cultural continuity and foreign elements in Cajamarca, northern highlands of Peru: The case of the Middle Horizon]. Boletín de Arqueología PUCP, 14, 221-238.

Yacoub López, C. (2007). Identificación y cuantificación de impactos medioambientales generados por la minería de extracción de oro por lixiviación de cianuro. Caso Minería Yanacocha S.R.L., en Cajamarca, Perú [Identification and quantification of environmental impacts generated by gold extraction mining by cyanide leaching. Minera Yanacocha S.R.L. mining case, in Cajamarca, Peru]. Barcelona: UPC.

Young, K. R. (1988). Deforestation in landscapes with humid forests in the central Andes: Patterns and processes. In K. S. Zimmerer \& K. R. Young (Eds.), Nature's geography: New lessons for conservation in developing countries (pp. 75-99). Madison, WI: University of Wisconsin Press.

Younger, P. L., Banwart, S. A., \& Hedin, R. S. (2002). Mine water. Hydrology, pollution, remediation. Dordrecht: Kluwer Academic Publishers. 


\section{COGITATIO}

\section{About the Authors}

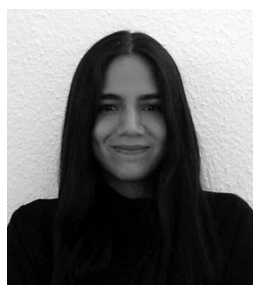

Margarita Macera is a Peruvian Architect who received her undergraduate degree at Universidad Nacional de Ingeniería and a post-graduate Master in Urbanism and Strategic Spatial Planning. She is presently a PhD candidate at KU Leuven. Her research focuses on the rural and urban Andean landscapes of Peru, and the anticipation of (post)mining landscapes in the (North) Andes of Peru.

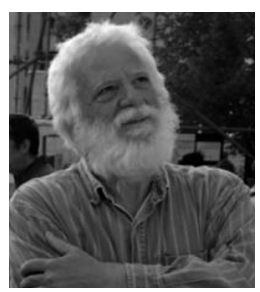

Bruno De Meulder is a Professor of Urbanism at the University of Leuven. His teaching and research travels between various practices of urban design and theory and history of urbanism. His work continuously combines design with research in his own post-industrial European context and within a number of post-colonial situations that are characterized by fast and dynamic development.

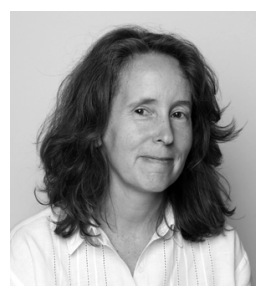

Kelly Shannon is a Professor of Urbanism at the University of Leuven. Her design research is at the intersection of analysis, mapping and new cartographies and design. It primarily focuses on the evolving relation of landscape, infrastructure and urbanization in the Asian public sector. 